\title{
Beroepenindeling ROA-CBS 2014 (BRC 2014)
}

Citation for published version (APA):

Fouarge, D., \& Dijksman, S. (2015). Beroepenindeling ROA-CBS 2014 (BRC 2014). ROA. ROA Technical Reports No. 005 https://doi.org/10.26481/umarot.2015005

Document status and date:

Published: 01/01/2015

DOI:

10.26481/umarot.2015005

\section{Please check the document version of this publication:}

- A submitted manuscript is the version of the article upon submission and before peer-review. There can be important differences between the submitted version and the official published version of record.

People interested in the research are advised to contact the author for the final version of the publication, or visit the DOI to the publisher's website.

- The final author version and the galley proof are versions of the publication after peer review.

- The final published version features the final layout of the paper including the volume, issue and page numbers.

Link to publication

\footnotetext{
General rights rights.

- You may freely distribute the URL identifying the publication in the public portal. please follow below link for the End User Agreement:

www.umlib.nl/taverne-license

Take down policy

If you believe that this document breaches copyright please contact us at:

repository@maastrichtuniversity.nl

providing details and we will investigate your claim.
}

Copyright and moral rights for the publications made accessible in the public portal are retained by the authors and/or other copyright owners and it is a condition of accessing publications that users recognise and abide by the legal requirements associated with these

- Users may download and print one copy of any publication from the public portal for the purpose of private study or research.

- You may not further distribute the material or use it for any profit-making activity or commercial gain

If the publication is distributed under the terms of Article $25 \mathrm{fa}$ of the Dutch Copyright Act, indicated by the "Taverne" license above, 


\section{Beroepenindeling ROA-CBS 2014 (BRC 2014)}

\section{ROA Technical Report}

ROA-TR-2015/5

Researchcentrum voor Onderwijs en Arbeidsmarkt | ROA

Research Centre for Education and the Labour Market | ROA

Centraal Bureau voor de Statistiek | CBS

Statistics Netherlands | CBS 


\section{Beroepenindeling ROA-CBS 2014 (BRC 2014)}

ROA-TR-2015/5

May 2015

Research Centre for Education and the Labour Market Maastricht University

P.O. Box 616, 6200 MD Maastricht, The Netherlands

$\mathrm{T}+31433883647 \mathrm{~F}+31433884914$

secretary-roa-sbe@maastrichtuniversity.nl www.roa.nl

\section{Statistics Netherlands}

P.O. Box 24500, 2490 HA The Hague, The Netherlands $\mathrm{T}+31703373800$

www.cbs.nl 


\section{Inhoudsopgave}

Pagina

Inhoudsopgave 3

1 Inleiding 5

2 Overgang SBC 1992 op ISCO 2008

3 Uitgangspunten BRC 2014

Verwijzingen $\quad 15$

Bijlage 1: BRC2014: Beroepsklasse, -segment en -groep

Bijlage 2: Aantal werkenden en aandeel ISCO2008 in BRC2014 beroepsgroep, EBB 2013 kwartaal 2 t/m 2014 kwartaal 1

Bijlage 3a: Belangrijkste BGR128 beroepsgroep (oude ROA classificatie) per BRC2014 beroepsgroep, 2010-2012*

Bijlage 3b: Belangrijkste BRC2014 beroepsgroep per BGR128 beroepsgroep (oude ROA classificatie), 2010-2012* 



\section{$1 \quad$ Inleiding}

De Beroepenindeling ROA CBS 2014 (afgekort BRC 2014) die in dit document wordt toegelicht is een van de International Standard Classification of Occupations 2008 (ISCO 2008) afgeleide indeling bedoeld voor toepassing in analyses en statistieken op nationaal niveau. De BRC 2014 is tot stand gekomen na overleg tussen de organisaties ROA en CBS. ${ }^{1}$ Aanleiding voor het overleg was het gegeven dat vanaf 2013 door het CBS het beroep van respondenten in de Enquête Beroepsbevolking (EBB) na het herontwerp van de persoonsenquêtes niet meer wordt ingedeeld volgens de Standaard Beroepenclassificatie 1992 (SBC 1992) maar alleen nog volgens de ISCO 2008. De achtergrond van deze wijziging wordt toegelicht in paragraaf 2 .

De BRC 2014 is afgeleid van de ISCO 20083 en 4 digits beroepencodes. De BRC 2014 is in een aantal opzichten een verbetering ten opzichte van de ISCO 2008 voor toepassing op nationaal niveau. Ten eerste zijn de groeperingen van de BRC 2014 op een zodanige wijze samengesteld dat bij gebruik in een steekproefonderzoek als de EBB de omvang ervan voldoende groot is voor publicatie door het CBS op Statline en of om betrouwbare arbeidsmarkt analyses te kunnen uitvoeren door het ROA en andere gebruikers van de EBB. ${ }^{2}$ Ten tweede is in de BRC 2014 de herkenbaarheid van de groeperingen verbeterd door aanpassingen in de naamgeving van de beroepen. In paragraaf 3 wordt hier nader op ingegaan.

Het ROA zal vanaf 2014 de BRC 2014 gebruiken binnen het Project OnderwijsArbeidsmarkt (POA) voor het opstellen van de arbeidsmarktprognoses naar beroep en de rapportage hierover, en de actuele arbeidsmarktinformatie in de ArbeidsmarktInformatieSysteem (AIS). ${ }^{3}$ Ook het CBS zal voor nationale analyses en statistieken de BRC 2014 gebruiken in plaats van de SBC 1992, en gebruikt de ISCO 2008 in internationaal vergelijkende onderzoeken.

De SBC 1992 die tot nog toe door het CBS werd gebruikt voor publicatie onderscheidt op het laagste niveau 1211 beroepen, 121 beroepsgroepen, 43 beroepsklassen en 5 beroepsniveaus. Een belangrijk deel van de 1211 beroepen heeft te weinig vulling om in steekproefonderzoek betrouwbaar te kunnen waarnemen. Door het CBS zijn daarom op statline alleen de 121 beroepsgroepen van de SBC 1992 gebruikt om te publiceren over beroep. De van de SBC 1992 afgeleide ROA indeling van beroepen makkte een onderscheid tussen 127 beroepsgroepen, 43 beroepssegmenten en 11 beroepsklassen (ROA 2002). De BRC 2014 maakt een onderscheid tussen 114 beroepsgroepen, 41 beroepssegmenten en 13 beroepsklassen en voldoet in termen van de detaillering van de beroepeninformatie als alternatief voor de SBC 1992. De meest gedetailleerde

\footnotetext{
${ }^{1}$ Hierbij is de input verwerkt van UWV-werkbedrijf, TNO en de Project Onderwijs-Arbeidsmarkt (POA)-begeleidingscommissie van het ROA.

Kleine en voor de Nederlandse arbeidsmarkt minder relevante beroepsgroepen zijn samengevoegd, terwijl grote groepen van de ISCO 2008 juist zijn opgesplitst.

${ }^{3}$ Voor de laatste publicatie, zie ROA (2013).
} 
informatie over beroepen (de 436 unit groups van de ISCO 2008) blijft beschikbaar in de EBB, waardoor het mogelijk is om ten behoeve van maatwerkonderzoek in meer detail in te zoomen binnen bepaalde beroepsgroepen. Vanuit deze unit groups kan ook worden geaggregeerd naar de standaard aggregaties van de ISCO 2008 waarmee de op de Nederlandse arbeidsmarkt uitgeoefende beroepen vergeleken kunnen worden met die van andere landen.

In deze notitie wordt in hoofdstuk 2 ingegaan op de achtergrond van het herontwerp van de EBB en de overgang van de SBC 1992 op de ISCO 2008. In hoofdstuk 3 worden de uitgangspunten van de BRC 2014 nader toegelicht. Bijlage 1 toont de volledige structuur van de BRC 2014. In bijlage 2 is de relatie tussen de ISCO 2008 en de BRC 2014 weergegeven, waarbij de verdeling van ISCO 20084 digit beroepen binnen elke BRC 2014 beroepsgroep wordt weergegeven. In bijlagen 3a en 3b wordt ingegaan op de verschillen tussen de BRC 2014 en de oude ROA beroepenindeling. 


\section{Overgang SBC 1992 op ISCO 2008}

In 2007 is binnen het CBS een project gestart om met behulp van de nieuwste inzichten en technologieën de sociale statistieken kosteneffectiever tot stand te laten komen. Om dit te bewerkstelligen is gebruik gemaakt van beschikbare informatie uit registraties en is telefonische waarneming en waarneming via internet in een volledig mixed-mode design in de EBB geïntroduceerd. Daarnaast is besloten om wettelijke outputverplichtingen voor de typeervariabelen als beroep, bedrijf en onderwijs als uitgangspunt te nemen. Reden daarvoor is dat de bestaande typeerprocessen sowieso vervangen moesten worden omdat deze niet geschikt waren voor waarneming via internet. Ook voor beroep bleek het om technische redenen niet mogelijk de huidige methode van waarnemen waarmee de SBC 1992 wordt opgeleverd te handhaven in het mixed-mode design van de EBB. Bij de inrichting van het nieuwe typeerproces is ervoor gekozen om aan te sluiten bij internationale richtlijnen en dit zo kostenefficiënt mogelijk te doen. In het nieuwe typeerproces dat is ontwikkeld voor implementatie in het mixed-mode design van de EBB, wordt daarom alleen de data op basis van de ISCO 2008 op het meest gedetailleerde niveau (4 digits) opgeleverd.

\section{Bewerkingsmethode beroep voor herontwerp}

In de situatie vóór herontwerp werd de informatie die de persoon tijdens de enquête over zijn beroep gaf omgezet in zogenaamde bewerkingscodes. Dit gebeurde deels interactief en computergestuurd tijdens het interview en deels achteraf handmatig door een beroepentypeur. Deze bewerkingscodes konden daarna worden omgezet in codes van diverse beroepenclassificaties.

Tijdens het interactieve deel werd aan een respondent gevraagd welk beroep hij/zij uitoefende. Tijdens het interview werd het antwoord vergeleken met een set van ongeveer 300.000 reeds getypeerde beroepenantwoorden en werd de tekstuele overeenkomst bepaald. Vervolgens werd aan de respondent een lijst voorlopige beroepsbenamingen voorgelegd waaruit een keuze moest worden gemaakt. Als een keuze kon worden gemaakt was daarmee ook de bewerkingscode vastgelegd. Indien er teveel suggesties waren, werd een vervolgvraag gesteld, bijvoorbeeld naar de belangrijkste werkzaamheden, om het aantal keuzemogelijkheden verder te beperken. De open antwoorden waarvoor tijdens het interview geen suggestie kon worden gevonden werden achteraf op het CBS door beroepentypeurs van een bewerkingscode voorzien.

Er werd gewerkt met een lijst van ruim 2100 bewerkingscodes. Deze bewerkingscodes waren niet gelijk aan de classificatiecodes omdat de informatie over het beroep op een gedetailleerder niveau werd vastgelegd. Van de bewerkingscodes konden daarna de classificatiecodes worden afgeleid. In de meeste gevallen kon een bewerkingscode direct worden geconverteerd naar een classificatiecode, voor een deel van de bewerkingscodes waren aanvullende variabelen noodzakelijk. Voor de omzetting van de bewerkingscodes naar de SBC 
1992, de ISCO 1988 of ISCO 2008 werden de variabelen hoogst behaald opleidingsniveau, de richting van de hoogst behaalde opleiding, het aantal personen waaraan werd leiding gegeven, de positie in de werkkring of de bedrijfsactiviteit (SBI) gebruikt.

De bewerkingscodes zijn eind jaren 80 gemaakt ten behoeve van de SBC 1992 en de ISCO 1988. De ISCO 2008 is op een aantal terreinen gemoderniseerd en meer gedetailleerd dan de ISCO 1988. Ten opzichte van de SBC 1992 biedt de ISCO 2008 meer detail bijvoorbeeld op het gebied van ICT of gezondheidszorg. In die gebieden zijn de bewerkingscodes soms onvoldoende gedetailleerd waardoor niet altijd mogelijk is alle ISCO 2008 codes op het meest gedetailleerd niveau (4 digits) te kunnen afleiden.

\section{Bewerkingsmethode beroep na herontwerp}

In de situatie na herontwerp is de bewerkingsmethode voor beroep in zijn geheel herzien. $\mathrm{Er}$ is een nieuwe beroepenindex gemaakt die doorzocht wordt op tekstuele overeenkomst met de open antwoorden van respondenten op de vragen naar het beroep en de belangrijkste werkzaamheden. Met deze nieuwe zoeklijst kunnen de meest voorkomende antwoorden zoveel mogelijk automatisch (achteraf) worden getypeerd en is het rendement van de automatische typering sterk verbeterd.

Het nieuwe verwerkingsproces is opgeknipt in 4 stappen die alle achteraf worden uitgevoerd (back-office coding): In stap 1 wordt het antwoord op de vraag naar beroep automatisch getypeerd op grond van overeenkomst met de zoekindex. In stap 2 wordt voor het resterende deel het antwoord op de vraag naar de belangrijkste werkzaamheden toegevoegd. Zo kan het antwoord 'monteur' in stap 1 niet automatisch getypeerd worden, maar na toevoeging van bijvoorbeeld 'wasmachines repareren' wel. In de derde stap wordt voor een deel van de antwoorden de SBI en het soort leidinggevende taken als aanvullende variabelen gebruikt. Het deel dat na deze 3 stappen nog resteert wordt in de $4^{\mathrm{e}}$ stap handmatig getypeerd door een typeur.

\section{Beschikbare data over beroep voor en na herontwerp.}

De data over beroep die in de EBB voor het herontwerp (1996-2012) voor gebruikers beschikbaar is betreffen de 2100 bewerkingscodes, en de daarvan afgeleide codes van de SBC 1992, de ISCO 1988 en de ISCO 2008. De BRC 2014 die is afgeleid van de ISCO 2008 is ook voor die jaren beschikbaar. Van de ISCO 2008 zijn in de jaren 1996-2012 niet alle codes op het meest gedetailleerde niveau beschikbaar, bijvoorbeeld op het gebied van beroepen in de ICT.

Na herontwerp (2013 en verder) is in de EBB over beroep alleen nog de ISCO 2008 en de daarvan afgeleide BRC 2014 beschikbaar. Verslagjaar 2013 is het eerste jaar 
waarin de ISCO 2008 volledig is waargenomen volgens het nieuwe ontwerp ${ }^{4}$. In 2012 is de ISCO 2008 deels bepaald op basis van de methode voor herontwerp en deels op basis van de nieuwe methode ${ }^{5}$. In de jaren 2011 en daarvoor is alleen de methode vóór herontwerp gebruikt.

Omdat de methodes waarmee de ISCO 2008 voor en na herontwerp is waargenomen van elkaar verschillen, zal dit ook tot uiting komen in de data die voor en na herontwerp over beroep wordt opgeleverd. Dit heeft tot gevolg dat de verdeling van de beroepsbevolking over de categorieën van de ISCO 2008 voor en na herontwerp niet exact gelijk zijn.

\section{Documentatie voor gebruikers}

Om de overgang van de SBC 1992 op de ISCO 2008 voor gebruikers van de beroepenclassificatie te vergemakkelijken stelt het CBS 2 schakelschema's ter beschikking. Een gedetailleerd schema waarmee per code van de SBC 1992 of ISCO 2008 is aangegeven welke ISCO 2008 of SBC 1992 code van toepassing zou kunnen zijn. Daarnaast is een globaal schakelschema gemaakt waarin per SBC 1992 code, zoals waargenomen bij de Enquête Beroepsbevolking 2008-2010, de meest voorkomende ISCO 2008 code is weergegeven. Van belang hierbij is dat er geen een-op-een koppeling is tussen SBC 1992 en ISCO 2008.

Het CBS voorziet niet in een vertaling van de methodologische verantwoording van de ISCO 2008 die door de ILO is opgesteld (ILO 2012), wel voorziet het CBS in een lijst beroepenbenamingen die dient als toelichting van wat er volgens de definities van de ISCO 2008 tot een unit group behoort. Hierbij is de beroepenindex van de ILO als uitgangspunt genomen. In de lijst zijn per unit group beroepenbenamingen opgenomen uitgaande van het verwerkingsproces zoals dat vanaf verslagjaar 2012 in de EBB in productie is gegaan.

De hierboven genoemde documentatie is beschikbaar op de website van het CBS onder methoden/classificaties.

\footnotetext{
${ }^{4}$ Met uitzondering van 1 van de 5 panels dat in de laatste peiling in het eerste kwartaal nog via het oude design is bevraagd.

${ }^{5}$ In laatste kwartaal van 2012 is 1 van de 5 panels in de eerste peiling via het nieuwe design bevraagd. Tevens zijn in twee kwartalen in het zogenaamde dubbeldraaitraject verschillende panels waargenomen via het oude en het nieuwe design.
} 


\section{Uitgangspunten BRC 2014}

De ISCO 2008 indeling van beroepen classificeert beroepen volgens de belangrijkste taken en activiteiten (ILO 2012). De indeling onderscheidt 10 zogenaamde major groups (1 digit ISCO), 43 sub-major groups (2 digits ISCO), 130 minor groups (3 digits ISCO) en 436 unit groups (4 digits ISCO).

In de BRC 2014 worden de ISCO 2008 minor groups (3 digits) gehanteerd als uitgangspunt voor het definiëren van beroepsgroepen. ${ }^{6}$ Echter, bij de nieuwe indeling wordt op een aantal punten afgeweken van dit uitgangspunt:

1) indien bepaalde minor groups te klein zijn om deze op een statistische betrouwbare manier te kunnen onderscheiden,

2) indien bepaalde minor groups groot genoeg zijn om daarbinnen onderscheid in aan te brengen die voor de arbeidsmarkt relevant is,

3) indien bepaalde unit groups uit verschillende minor groups veel verwantschap vertonen in hun sector van activiteit en/of opleidingsachtergrond.

De term beroep wordt gehanteerd als Nederlandse vertaling van de term unit group en ook voor de detaillering daarbinnen, maar niet voor de hogere aggregatieniveaus van de BRC 2014, dit zijn de zogenaamde beroepsgroepen, beroepssegmenten en op het hoogste niveau de beroepsklassen.

\section{Kleine minor groups}

Minor groups die te klein zijn in omvang om zinvolle en betrouwbare arbeidsmarktinformatie of arbeidsmarktprognoses te kunnen opstellen worden zoveel mogelijk bijgevoegd bij andere, vergelijkbare minor groups op eenzelfde niveau. Bijvoorbeeld minor group 'Managers landbouw, bosbouw en visserij' (ISCO 131) is te klein om onderscheiden te kunnen worden als een aparte beroepsgroep en wordt samengenomen met minor group 'Managers industrie, mijnbouw, bouwnijverheid en logistiek' (ISCO 132). In beide groepen werken veel technisch geschoold personen. Deze vormen samen de beroepsgroep 'Managers productie'.

Een ander voorbeeld betreft minor group 'Kassiers, incassomedewerkers' (ISCO 421). Ook deze groep is relatief klein en wordt daarom samen genomen met minor group 'Overig administratief personeel' (ISCO 441) in de beroepsgroep 'Administratief medewerkers'. In beide gevallen zijn vooral mensen met een algemene opleiding of een opleiding met een financieel/administratief achtergrond in die beroepen werkzaam.

Kleine minor groups die bestaan uit meerdere kleine beroepen worden ook zoveel mogelijk samengevoegd met andere minor groups om te voorkomen dat het niet goed mogelijk is om aan te geven hoe de minor group is samengesteld naar de onderliggende beroepen. De grens wordt daarbij voor een jaarcijfer uit de EBB

\footnotetext{
${ }^{6}$ De SBC'92 3-digit codes zijn nu het uitgangspunt voor de ROA beroepsgroepen.
} 
gelegd op een beroepsgroepomvang van minimaal 15 duizend personen. Bij het jaarcijfer 2013 zijn er in de BRC 20144 beroepsgroepen waarvoor dit alsnog het geval is (zie bijlage 2). Deze beroepsgroepen bleken moeilijk te combineren met een andere beroepsgroep vanwege onderscheidende werkzaamheden (bibliothecarissen en conservatoren), beroepsniveau (politie-inspecteurs) of omdat de beroepsgroep relatief nieuwe beroepen bevat die de komende jaren mogelijk zullen toenemen in omvang (elektronisch ingenieurs of televisie-technici).

\section{Grote minor groups}

Sommige minor groups zijn zo groot dat een verdere detaillering op het niveau van de ISCO 4 digits mogelijk is. Een verder detaillering is ook relevant omdat het de mogelijkheid biedt om duidelijk voor de arbeidsmarkt herkenbare beroepen te onderscheiden. Zo bevat de minor group 'Overige vakspecialisten in de gezondheidszorg' (ISCO 325) een grote groep 'Medische praktijkassistenten' (ISCO 3256), overwegend $\mathrm{MBO}$-opgeleiden met een verplegingsachtergrond. Door deze minor group te splitsen kunnen de 'Medische praktijkassistenten' (waaronder doktersassistenten) onderscheiden worden van de 'Medisch vakspecialisten'. Ook de ISCO minor group 'Overige specialisten in de gezondheidszorg' (ISCO 226) bevat betrekkelijk veel werkenden. Het omvat bovendien beroepen waarvoor het vereist opleidingsniveau uiteenloopt, zoals 'Fysiotherapeuten' (ISCO 2264) die overwegend HBO geschoold zijn en 'Tandartsen' (ISCO 2261) en 'Apothekers' (ISCO 2262), beroepen die om een WO diploma vragen. De groep 'Overige specialisten in de gezondheidszorg' is daarom gesplitst in de beroepsgroepen 'Artsen' en 'Fysiotherapeuten', waarbij unit groups 'Tandartsen' en 'Apothekers' samengevoegd worden bij de ISCO minor group 'Artsen' (ISCO 221).

Een ander voorbeeld betreft de minor groep 'Machinemonteurs, montage en reparatie' (ISCO 723). Binnen deze groep is er een grote unit group 'Automonteurs' (ISCO 7231) overwegend bestaand uit MBO'ers met een opleiding voertuigtechniek. Het beroep van 'Automonteur' is daarom onderscheiden van dat van 'Machinemonteur'.

\section{Verwante beroepen}

Verwante beroepen, vanuit het perspectief van de sector waar men werkzaam is en/of vanuit het perspectief van de opleidingsachtergrond van personen die werkzaam zijn in die beroepen, die in verschillende ISCO 2 digit codes (sub-major groups) zijn ingedeeld worden in de BRC 2014 bij elkaar genomen. Bijvoorbeeld, ISCO maakt in 2 verschillende sub-major groups onderscheid tussen 'Chef-koks' (ISCO 3434) en 'Koks' (ISCO 5120). Chef-koks en Koks worden in de BRC 2014 bij elkaar genomen omdat beide beroepsgroepen werkzaam zijn in dezelfde sector (Horeca) en overwegend dezelfde opleidingsachtergrond genieten (doorgaans een MBO Horeca opleiding). Beide worden ondergebracht bij de beroepsgroep 'Koks', dat onderdeel vormt van beroepssegment 'Medewerkers persoonlijke dienstverlening'. 
Bij het onderbrengen van unit groups naar een andere minor group is er rekening gehouden met de gevolgen die dit kan hebben voor een goede waarneming van het beroep in de tijdreeksen. Voor de jaren 1996-2012 maakt het CBS gebruik van in de EBB verzamelde bewerkingscodes voor beroepen om de ISCO 2008 beroepen te construeren. Echter in sommige gevallen kunnen de bewerkingscodes niet goed worden toegekend aan een bepaald unit of zelfs minor group, en krijgen werkenden een ISCO-code toegekend op een hoger aggregatieniveau (zogenaamde vangnetcode). In de ISCO 2008 worden 151 vangnetcodes onderscheiden waarvan er zo'n 50 zijn gebruikt. In die gevallen waar een beroep in de jaren voor het herontwerp van de EBB in een vangnetcode van een minor group valt, verdient het de voorkeur het betreffende beroep te houden binnen de minor group waar het thuishoort, dan onder te brengen in een andere minor group.

\section{Naamgeving beroepen}

De officiële door de ILO gecoördineerde vertaling van de categorieën van de ISCO 2008 is soms betrekkelijk technisch en niet zo herkenbaar omdat getracht is tot een compromis in het Nederlandse en Vlaamse taalgebruik te komen. Daardoor is de herkenbaarheid van de beroepen voor de Nederlandse arbeidsmarkt in sommige gevallen verloren gegaan. Om die reden wordt er in de BRC 2014 soms afgeweken van de in ISCO gebruikte omschrijvingen van de minor en unit groups zodat de beroepsgroepen voor de gebruikers van de BRC 2014 beter herkenbaar zijn. Bij dergelijke veranderingen in de naamgeving wordt er gebruik gemaakt van een benaming die intuïtief herkenbaarder is ${ }^{7}$, van de naam van de grootste unit group ${ }^{8}$, of een combinatie van grote unit groups binnen de minor group. Bijvoorbeeld het ISCO beroep 'Secretarieel medewerkers, algemeen' (ISCO 412) wordt aangepast in 'Secretaresses'. Een ander voorbeeld betreft 'Office managers en gespecialiseerde secretaressen' (ISCO 334) die de naam 'Directiesecretaresses' krijgt.

Ook is er in de naamgeving van de beroepsgroepen naar gestreefd de term 'overig' te voorkomen omdat deze enkel betekenis krijgt als men weet welke andere beroepen deel uitmaken van dezelfde beroepssegment of -klasse. Bijvoorbeeld het beroep 'Overige vakspecialisten in de gezondheidszorg' (ISCO 325) krijgt simpelweg de naam 'Medisch vakspecialist'.

\section{Beroepsgroep Overig}

In de BRC 2014 is een beroepsgroep 'Overig' gemaakt waarin de unit groups van de ISCO 2008 zijn ondergebracht die niet relevant zijn voor de Nederlandse arbeidsmarkt. Dit zijn bijvoorbeeld de 'traditionele dorpshoofden' (ISCO 1113) of de

\footnotetext{
${ }^{7}$ Dit betekent dat sommige namen van beroepen niet de volledige lading van de beroepen behelst. Bijvoorbeeld het ISCO beroep 'Medewerkers drukkerij en kunstnijverheid' (ISCO 730) wordt ook als groep gebruikt, zonder dat 'Ambachtslieden werkend met hout, vlechtwerk' (ISCO 7317) en 'Ambachtslieden werkend met textiel, leder' (ISCO 7318), overigens kleine groepen werkenden, expliciet worden genoemd.

${ }^{8}$ Het beroep 'Schilders, schoonmakers bouwwerken' (ISCO 713) wordt vervangen in 'Schilders en behanger' dat het grootste beroep is binnen de unit.
} 
'waterdragers en houtverzamelaars' (ISCO 9624). De groep 'Overig' is ook gebruikt wanneer het beroep van respondenten van de EBB onbekend is.

Wanneer tijdens het coderen van de ISCO 2008 gebruik is gemaakt van vangnetcodes zijn deze zo veel mogelijk ondergebracht bij de best van toepassing zijnde beroepsgroep. Hierbij is indien mogelijk gebruik gemaakt van informatie over de wijze waarop tijdens het typeren (voor en na herontwerp) de bewerkingscodes of ISCO-codes worden toegekend. ${ }^{9}$

Als de vangnetcode niet goed in een beroepsgroep in te delen is, bijvoorbeeld bij de vangnetcode 7000 die gebruikt wordt wanneer er niets anders bekend is dan 'technisch medewerker' of 'monteur' of 'productiemedewerker' zijn deze vangnetcodes ondergebracht bij de beroepsgroep 'overig'.

Niveau-indeling

De beroepen in de BRC 2014 zijn ingedeeld naar beroepsniveau volgens de uitgangspunten van de ISCO 2008. De niveau-indeling van de ISCO 2008 is gevormd door beroepen die overeenkomen in niveau van de benodigde bekwaamheden en vaardigheden te combineren. Beroepsniveau geeft de complexiteit en omvang van taken weer die bij een beroep horen. De praktische uitwerking van het begrip vaardigheidsniveau gebeurt in de ISCO 2008 door toepassing van een of meer van de volgende criteria:

- De aard van het werk in relatie tot de karakteristieke taken bij een beroepsniveau

- Het voor een goede beroepsuitoefening benodigde onderwijsniveau

- De in een verwant beroep opgedane relevante werkervaring en/of on-thejob training.

Tijdens de bepaling de meest geëigende ISCO 2008 code van de op de Nederlandse arbeidsmarkt voorkomende beroepen volgens de definities van de ISCO 2008, bleek dat de beroepsniveaus van de ISCO 2008 niet homogeen zijn qua niveau van de voor de beroepen meest geëigende opleiding. Uitgedrukt in termen van het Nederlandse onderwijssysteem zijn in beroepsniveau 4 beroepen met wetenschappelijk en hoger niveau samengenomen, in beroepsniveau 3 beroepen met hoger en middelbaar niveau, in beroepsniveau 2 zijn beroepen met lager en middelbaar niveau en in beroepsniveau 1 beroepen met elementair en lager niveau.

De beroepsniveaus van de werkzame beroepsbevolking zijn niet rechtstreeks gerelateerd aan de beroepsklassen, -segmenten of -groepen van de BRC 2014 en worden afgeleid van de unit groups van de ISCO 2008. Van de 114 beroepsgroepen zijn er slechts 4 groepen niet homogeen qua beroepsniveau, dit zijn de 'managers z.n.d.', de 'koks', de 'militairen' en de beroepsgroep 'overig'. De relatie tussen de

\footnotetext{
9 Bijvoorbeeld wanneer niets anders bekend is dan 'chauffeur' werd in het oude design tijdens handmatig typeren meestal de bewerkingscode voor vrachtwagenchauffeurs (ISCO 8332) gebruikt, terwijl er in het nieuwe design de vangnetcode 8300 (Bestuurders voertuigen en bedieners mobiele installaties) wordt gebruikt. Om die reden zijn in de BRC 2014 de codes 8300,8330 en 8332 samengevoegd.
} 
ISCO 2008 beroepsniveaus en de beroepsgroepen van de BRC 2014 is weergegeven in bijlage 2.

\section{Structuur beroepenindeling}

De indeling van de ISCO beroepen in beroepsgroepen, -segmenten en -klassen volgens de uitgangspunten van de BRC 2014 levert 114 beroepsgroepen, 41 beroepssegmenten en 13 beroepsklassen op. Deze worden samengevat in Bijlage 1 . Hierbij is gekozen voor een hiërarchische structuur en codering, waarbij de beroepsgroepen genest zijn in de beroepssegmenten en de beroepssegmenten genest zijn in de beroepsklassen. In bijlage 2 is de exacte koppeling tussen de ISCO 2008 unit groups en de categorieën van de BRC 2014 gedocumenteerd, waarbij er ook inzicht is gegeven in de omvang van de unit groups binnen de beroepsgroepen.

Vanzelfsprekend verschilt BRC 2014 in vele opzichten van de oude ROAberoepenindeling (ROA 2002). Dit wordt inzichtelijk gemaakt in bijlagen 3a en 3b. Zo biedt BRC 2014 minder detail binnen de lerarenberoepen, maar juist meer detail binnen de economische en administratieve beroepsklasse. 


\section{Verwijzingen}

ILO (2012). International standard classification of occupations. Structure, group definitions and correspondence tables. Geneva: ILO.

ROA (2002). ROA-classificatiegids 2002. Maastricht: ROA-R-2002/3.

ROA (2013). De arbeidsmarkt naar opleiding en beroep tot 2018. Maastricht: ROA-R2013/11.

CBS Standaard beroepenclassificatie 1992; verbeterde editie 2001 (internet) 


\section{Bijlage 1}

BRC2014: Beroepsklasse, -segment en -groep

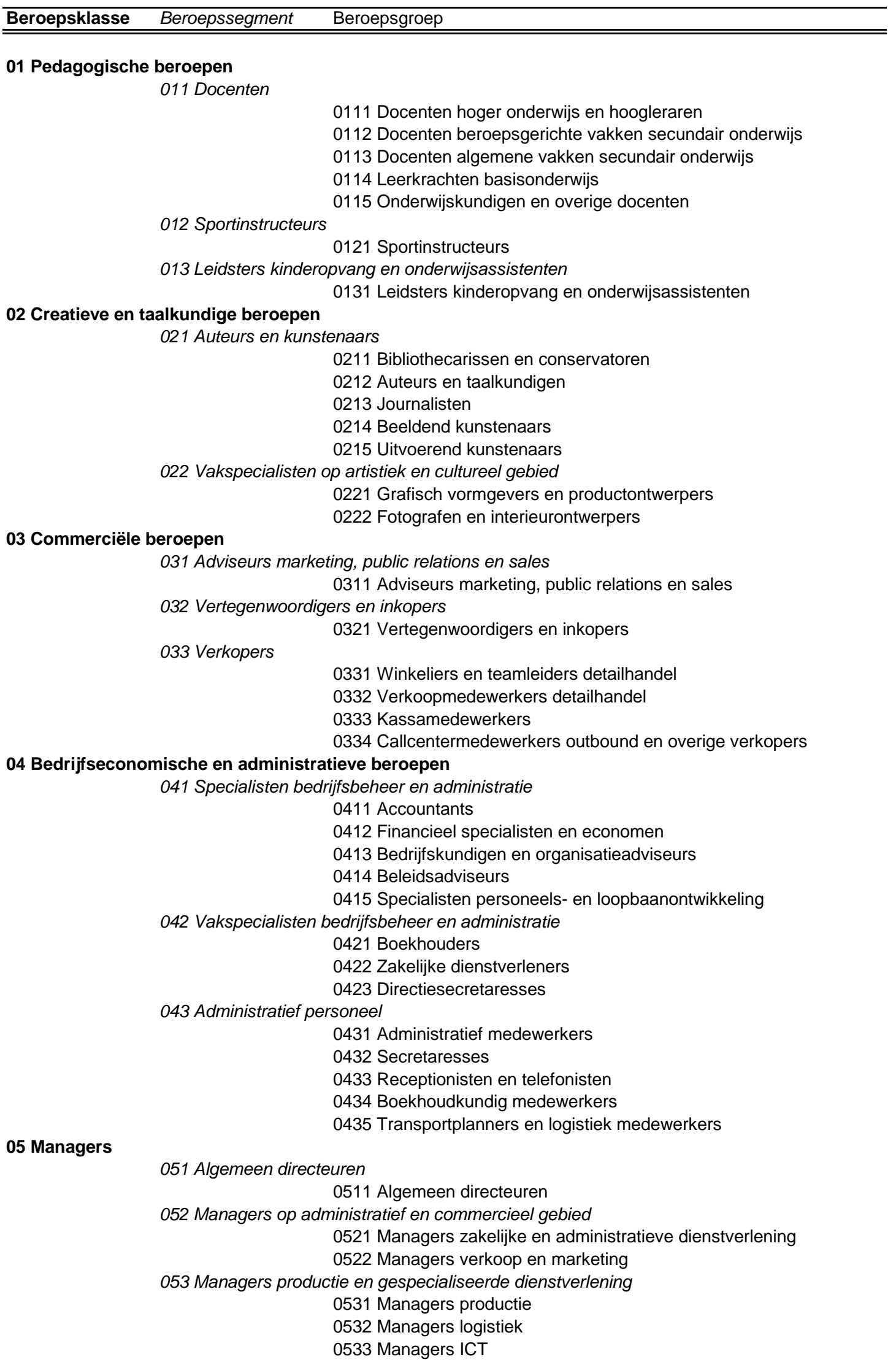




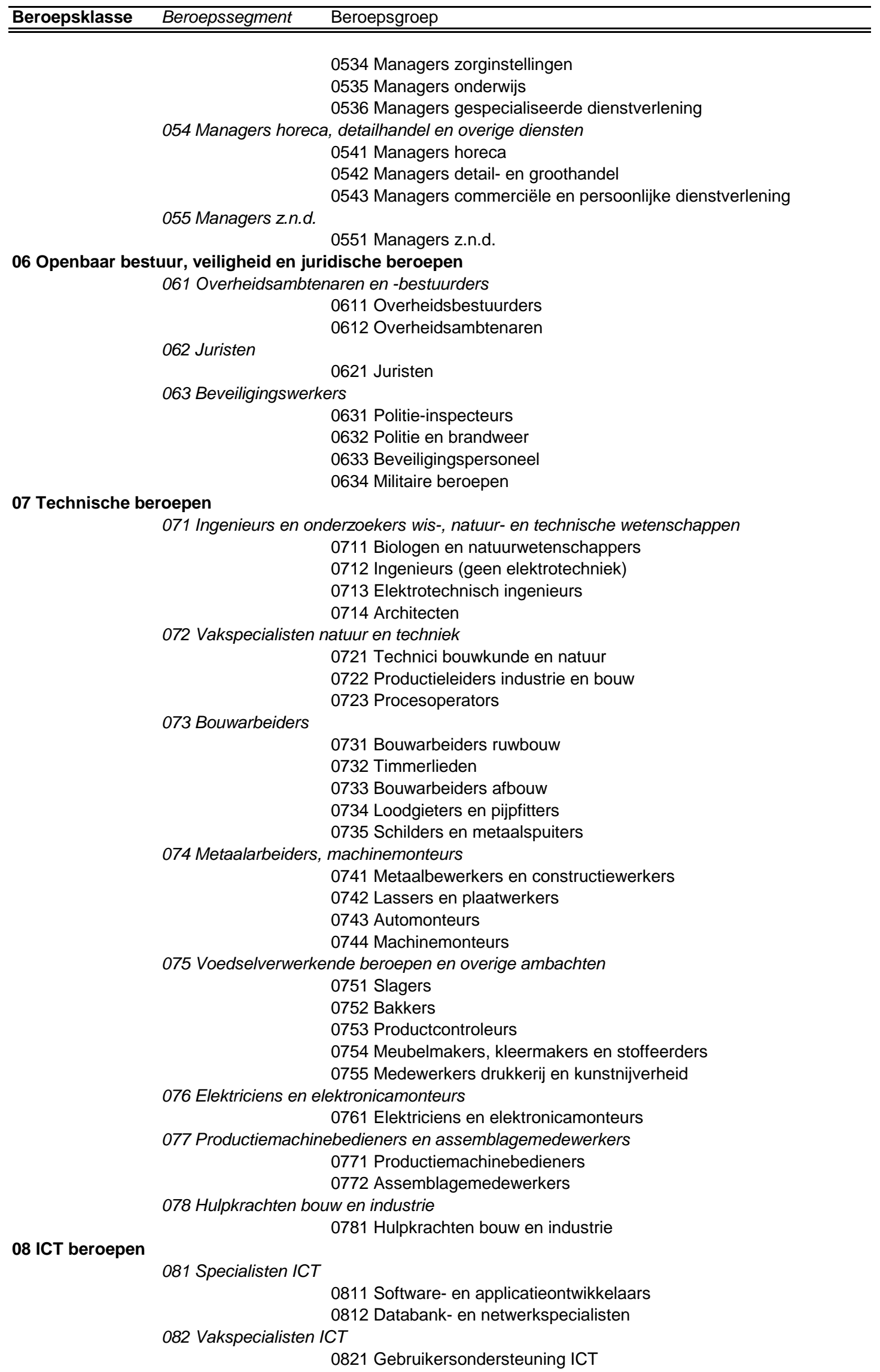


09 Agrarische beroepen

0822 Radio- en televisietechnici

091 Tuinders, akkerbouwers en veetelers

0911 Land- en bosbouwers

0912 Hoveniers, tuinders en kwekers

0913 Veetelers

092 Hulpkrachten landbouw

0921 Hulpkrachten landbouw

10 Zorg en welzijn beroepen

101 Artsen, therapeuten en gespecialiseerd verpleegkundigen

1011 Artsen

1012 Gespecialiseerd verpleegkundigen

1013 Fysiotherapeuten

102 Specialisten op maatschappelijk gebied

1021 Maatschappelijk werkers

1022 Psychologen en sociologen

103 Vakspecialisten gezondheidszorg

1031 Laboranten

1032 Apothekersassistenten

1033 Verpleegkundigen (mbo)

1034 Medisch praktijkassistenten

1035 Medisch vakspecialisten

104 Sociaal werkers, groeps- en woonbegeleiders

1041 Sociaal werkers, groeps- en woonbegeleiders

11 Dienstverlenende beroepen

1051 Verzorgenden

111 Medewerkers persoonlijke dienstverlening

1111 Reisbegeleiders

1112 Koks

1113 Kelners en barpersoneel

1114 Kappers en schoonheidsspecialisten

1115 Conciërges en teamleiders schoonmaak

1116 Verleners van overige persoonlijke diensten

112 Schoonmakers en keukenhulpen

1121 Schoonmakers

1122 Keukenhulpen

12 Transport en logistiek beroepen

121 Bestuurders voertuigen en bedieners mobiele machines

1211 Dekofficieren en piloten

1212 Chauffeurs auto's, taxi's en bestelwagens

1213 Buschauffeurs en trambestuurders

1214 Vrachtwagenchauffeurs

1215 Bedieners mobiele machines

122 Hulpkrachten transport en logistiek

1221 Laders, lossers en vakkenvullers

13 Overig

1222 Vuilnisophalers en dagbladenbezorgers

131 Overig

1311 Overig

1311 Overig 
Bijlage 2

Aantal werkenden en aandeel ISCO2008 in BRC2014 beroepsgroep, EBB 2013 kwartaal 2 t/m 2014 kwartaal 1

*Omvang beroepsgroep te klein om betrouwbare uitspraken te kunnen doen over omvang van onderliggende ISCO2008

$x \mathbf{1 . 0 0 0}$

Beroepsklasse, -segment, -groep en ISCO2008 aantal $\%$

$\begin{array}{ll}\text { 01-Pedagogische beroepen } & 567\end{array}$

$\begin{array}{lr}\text { 011-Docenten } & 407\end{array}$

0111-Docenten hoger onderwijs en hoogleraren $\quad 46$

2310 Hoogleraren en andere docenten hoger onderwijs $\quad 46$

0112-Docenten beroepsgerichte vakken secundair onderwijs $\quad 32$

2320 Docenten beroepsgerichte vakken secundair onderwijs $\quad 32$

0113-Docenten algemene vakken secundair onderwijs $\quad 103$

2330 Docenten algemene vakken secundair onderwijs $\quad 103$

$\begin{array}{lr}\text { 0114-Leerkrachten basisonderwijs } & 164\end{array}$

2341 Docenten basisonderwijs $\quad 117$

2352 Docenten speciaal onderwijs $\quad 23$

2300 (vangnet) Docenten $\quad 20$

2342 Docenten voorschools onderwijs

2340 (vangnet) Docenten basisonderwijs en voorschoolse onderwijs

0115-Onderwijskundigen en overige docenten

2359 Onderwijsbegeleiders en -adviseurs n.e.g.

2351 Specialisten op het gebied van onderwijsmethoden

2354 Muziekleraren (particulier)

2355 Kunstleraren (particulier)

2356 Opleiders en trainers op het gebied van informatica

2353 Docenten inburgering en docenten Nederlands als tweede taal

2350 (vangnet) Overige docenten en onderwijskundigen

012-Sportinstructeurs

0121-Sportinstructeurs

3422 Sporttrainers en zweminstructeurs

3423 Fitnessinstructeurs en leiders van recreatieprogramma's

3421 Atleten en andere sportbeoefenaren

3420 (vangnet) Sportbeoefenaren, -trainers en fitnessinstructeurs

013-Leidsters kinderopvang en onderwijsassistenten

0131-Leidsters kinderopvang en onderwijsassistenten

5311 Kinderverzorgers

5312 Onderwijsassistenten

5310 (vangnet) Kinderverzorgers en onderwijsassistenten

100

100

100

71

14

12

2

0

62

$28 \quad 45$

$16 \quad 26$

$8 \quad 12$

$5 \quad 8$

35

24

0

35

35

22

11

2

0

125

125

96

29

0

207

129

021-Auteurs en kunstenaars

0211-Bibliothecarissen en conservatoren

2622 Bibliothecarissen

2621 Archivarissen en conservators

2620 (vangnet) Bibliothecarissen, archivarissen en conservators

0212-Auteurs en taalkundigen

2641 Auteurs, technisch schrijvers

2643 Vertalers, tolken en andere taalkundigen

2640 (vangnet) Auteurs, journalisten en taalkundigen

0213-Journalisten

2642 Journalisten

0214-Beeldend kunstenaars

2651 Beeldend kunstenaars

0215-Uitvoerend kunstenaars

2652 Musici, zangers en componisten

2654 Regisseurs en producenten televisie, film en theater

2655 Acteurs 
2659 Entertainment artiesten

2656 Omroepers voor radio, televisie en andere media

2653 Dansers en choreografen

2650 (vangnet) Scheppende en uitvoerende kunstenaars

022-Vakspecialisten op artistiek en cultureel gebied

0221-Grafisch vormgevers en productontwerpers

2166 Grafisch vormgevers en multimedia vormgevers

2163 Product- en kledingontwerpers

0222-Fotografen en interieurontwerpers

3431 Fotografen

3432 Interieurontwerpers en decorateurs

3435 Vakspecialisten televisie- en theaterproductie

3433 Vakspecialisten galerieÙn, musea en bibliotheken

3430 (vangnet) Vakspecialisten op artistiek, cultureel en culinair gebied

03-Commerciële beroepen

031-Adviseurs marketing, public relations en sales

0311-Adviseurs marketing, public relations en sales

2431 Specialisten reclame en marketing

2432 Specialisten public relations

2433 Vertegenwoordigers en accountmanagers industrie

2434 Vertegenwoordigers informatie- en communicatietechnologie

2430 (vangnet) Specialisten marketing, sales en public relations

032-Vertegenwoordigers en inkopers

0321-Vertegenwoordigers en inkopers

3322 Vertegenwoordigers, accountmanagers retail en exportmanagers

3323 Inkopers

3321 Verzekeringsagenten

3324 Commissionairs

3320 (vangnet) In- en verkopers en commissionairs

033-Verkopers

0331-Winkeliers en teamleiders detailhandel

5221 Winkeliers

5222 Teamleiders detailhandel

0332-Verkoopmedewerkers detailhandel

5223 Verkoopmedewerkers detailhandel

5220 (vangnet) Verkopers in winkels

0333-Kassamedewerkers

5230 Kassamedewerkers en kaartverkopers

0334-Callcentermedewerkers outbound en overige verkopers

5244 Callcentermedewerkers outbound

5246 Verkopers in fastfoodrestaurants en snackbars

5242 Demonstrateurs

5211 Markt- en kioskverkopers

5249 Verhuurmedewerkers en verkopers n.e.g.

5200 (vangnet) Verkopers

5245 Pompbedienden

5243 Colporteurs

5241 Mannequins en modellen

5212 Straatverkopers voedsel

5210 (vangnet) Straat- en marktverkopers

5240 (vangnet) Overige verkopers

04-Bedrijfseconomische en administratieve beroepen

041-Specialisten bedrijfsbeheer en administratie

0411-Accountants
27 
2411 Accountants

0412-Financieel specialisten en economen

2412 Financieel en beleggingsadviseurs

2413 Financieel analisten

2410 (vangnet) Financieel specialisten

0413-Bedrijfskundigen en organisatieadviseurs

2421 Bedrijfskundigen en organisatieadviseurs

2420 (vangnet) Specialisten personeel, organisatie en beleidsadvies

0414-Beleidsadviseurs

2422 Beleidsadviseurs

0415-Specialisten personeels- en loopbaanontwikkeling 2423 Specialisten personeels- en loopbaanontwikkeling

042-Vakspecialisten bedrijfsbeheer en administratie

3313 Boekhouders, financieel administrateurs en assistent accountants

3312 Medewerkers kredieten en leningen

3315 Taxateurs en schade-experts

3314 Actuarieel, wiskundig en statistisch analisten

3311 Effecten- en valutahandelaren en -makelaars

3310 (vangnet) Financieel en wiskundig vakspecialisten

0422-Zakelijke dienstverleners

3339 Zakelijke dienstverleners n.e.g.

3334 Makelaars onroerend goed en vastgoedbeheerders

3333 Arbeidsbemiddelaars en uitzendbureaumedewerkers

3332 Organisatoren van conferenties en evenementen

3331 Inklaringsagenten en expediteurs

3330 (vangnet) Zakelijke dienstverleners

0423-Directiesecretaresses

3343 Directie-, project- en internationaal secretaressen

3341 Office managers

3344 Medisch secretaressen

3342 Juridisch secretaressen

3340 (vangnet) Office managers en gespecialiseerde secretaressen

043-Administratief personeel

0431-Administratief medewerkers

4110 Administratief medewerkers, algemeen

4416 Medewerkers personeelsadministratie

4000 (vangnet) Administratief personeel

4415 Archiverings- en kopieermedewerkers

4211 Kassiers en baliemedewerkers bank

4411 Bibliotheekmedewerkers

4214 Incassomedewerkers

4212 Bookmakers, croupiers

4419 Administratief assistenten n.e.g.

4413 Codeurs, correctoren

4400 (vangnet) Overig administratief personeel

4210 (vangnet) Kassiers, incassomedewerkers

4213 Lommerdhouders en geldschieters

4410 (vangnet) Overig administratief personeel 
4120 Secretarieel medewerkers, algemeen

4132 Medewerkers data-invoer

4131 Typisten en tekstverwerkers

4130 (vangnet) Typisten en medewerkers data-invoer

433-Receptionisten en telefonisten

4225 Informatieverstrekkers

4226 Receptionisten, algemeen

4222 Callcentermedewerkers inbound

4223 Telefonisten

4221 Reisconsulenten en reisbureaumedewerkers

4229 Klantenvoorlichters n.e.g.

4227 Interviewers voor enquÛtes en marktonderzoek

4224 Hotelreceptionisten

4220 (vangnet) Klantvoorlichters

0434-Boekhoudkundig medewerkers

4312 Administratief medewerkers statistiek, financiÙn en verzekeringen

4311 Boekhoudkundig medewerkers

4313 Loonadministrateurs

4310 (vangnet) Boekhoudkundig medewerkers

0435-Transportplanners en logistiek medewerkers

4321 Logistiek medewerkers, medewerkers materiaal-, voorraadplanning en -beheer

4322 Werkvoorbereiders, productieplanners en orderbegeleiders

4323 Transportplanners

4320 (vangnet) Magazijnbeheerders en administratief productie- en transportpersoneel

05-Managers

051-Algemeen directeuren

0511-Algemeen directeuren

1120 Topbestuurders en algemeen directeuren van grote ondernemingen

052-Managers op administratief en commercieel gebied

0521-Managers zakelijke en administratieve dienstverlening

1211 Financieel managers

1219 Managers zakelijke en administratieve dienstverlening n.e.g.

1212 Managers personeel en organisatie

1213 Managers beleid en planning

1210 (vangnet) Managers zakelijke en administratieve dienstverlening

0522-Managers verkoop en marketing

1221 Managers verkoop en marketing

1223 Managers onderzoek en ontwikkeling (R\&D)

1222 Managers reclame en public relations

1220 (vangnet) Managers verkoop, marketing en ontwikkeling

053-Managers productie en gespecialiseerde dienstverlening

0531-Managers productie

1321 Managers industrie

1323 Managers bouwnijverheid

1322 Managers mijnbouw

1311 Managers landbouw en bosbouw

1310 (vangnet) Managers landbouw, bosbouw en visserij

1320 (vangnet) Managers industrie, mijnbouw, bouwnijverheid en logistiek

1312 Managers aquacultuur en visserij

0532-Managers logistiek

1324 Managers logistiek, distributie en aanverwante gebieden

0533-Managers ICT

1330 Managers informatie- en communicatietechnologie 
1342 Managers gezondheidszorg

1344 Managers sociale dienstverlening

1341 Managers kinderopvang

1343 Managers ouderenzorg

1340 (vangnet) Managers gespecialiseerde dienstverlening

535-Managers onderwijs

1345 Managers onderwijs

0536-Managers gespecialiseerde dienstverlening

1349 Managers gespecialiseerde dienstverlening n.e.g.

1346 Managers financiÙle dienstverlening en verzekeringen

11

7

1

54-Managers horeca, detailhandel en overige diensten

0541-Managers horeca

1412 Restaurantmanagers

1411 Hotelmanagers

1410 (vangnet) Managers horeca

0542-Managers detail- en groothandel

1420 Managers detail- en groothandel

0543-Managers commerciële en persoonlijke dienstverlening

1439 Managers commerciÙle en persoonlijke dienstverlening n.e.g.

1431 Managers recreatie en amusement

1430 (vangnet) Managers overige diensten

1

55-Managers z.n.d.

0551-Managers z.n.d.

1000 (vangnet) Managers

1100 (vangnet) Topbestuurders, leden wetgevende instanties, beleidvoerende functies

1400 (vangnet) Managers horeca, detailhandel en overige diensten

1200 (vangnet) Managers op administratief en commercieel gebied

1300 (vangnet) Managers productie en gespecialiseerde dienstverlening

061-Overheidsambtenaren en -bestuurders

0611-Overheidsbestuurders

1112 Ambtenaren in beleidvoerende functies

1114 Bestuurders van belangenorganisaties

1111 Leden wetgevende instanties

1110 (vangnet) Leden wetgevende instanties, beleidvoerende functies 
0633-Beveiligingspersoneel

5414 Beveiligingspersoneel

5413 Gevangenbewaarders

5419 Parkeerwachters, strandwachten en beveiligingswerkers n.e.g.

5410 (vangnet) Beveiligingswerkers

5400 (vangnet) Beveiligingswerkers

0634-Militaire beroepen

0310 Andere militaire rangen

0210 Onderofficieren

0110 Officieren

0000 (vangnet) Militaire beroepen

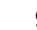

0

0

0

28

10

07-Technische beroepen

071-Ingenieurs en onderzoekers wis-, natuur- en technische wetenschappen 177

0711-Biologen en natuurwetenschappers

2131 Biologen, botanici, zo $\div$ logen

2133 Milieudeskundigen

2120 Wiskundigen, actuarissen en statistici

2132 Adviseurs op het gebied van landbouw, bosbouw en visserij

2113 Chemici

2111 Natuurkundigen en sterrenkundigen

2112 Meteorologen

2114 Geologen en geofysici

2110 (vangnet) Natuur- en aardwetenschappers

2130 (vangnet) Biologen, agrarisch en milieudeskundigen

0712-Ingenieurs (geen elektrotechniek)

2144 Werktuigbouwkundigen

2142 Weg- en waterbouwkundigen

2149 Ingenieurs n.e.g.

2000 (vangnet) Onderzoekers, ingenieurs, docenten en specialisten

2145 Chemisch ingenieurs

2100 (vangnet) Ingenieurs en onderzoekers wis-, natuur- en technische wetenschappen

2140 (vangnet) Ingenieurs (m.u.v. elektrotechnisch ingenieurs)

2141 Industrieel ingenieurs en productie-ingenieurs

2143 Milieutechnologen

2146 Mijnbouwkundigen en metaalkundigen

0713-Elektrotechnisch ingenieurs

2152 Elektronica- en hardware ingenieurs

2151 Elektrotechnisch ingenieurs

2153 Telecommunicatie-ingenieurs

2150 (vangnet) Ingenieurs elektrotechniek, elektronica en telecommunicatie

0714-Architecten

2161 Bouwkundig- en interieurarchitecten

2164 Stedenbouwkundigen en verkeersplanologen

2162 Landschapsarchitecten

2165 Cartografen en landmeetkundigen

2160 (vangnet) Architecten, planologen, landmeetkundigen en vormgevers

72 -Vakspecialisten natuur en techniek

0721-Technici bouwkunde en natuur

3118 Technisch tekenaars

3112 Technici weg- en waterbouw, bouwinspecteurs en landmeters

3111 Scheikundige en natuurkundige onderzoekstechnici

3115 Technici werktuigbouwkunde

3113 Elektrotechnici

3114 Technici elektronica 
3141 Analisten en laboranten levenswetenschappen (m.u.v. medisch)

3119 Vakspecialisten op het gebied van natuur- en technische wetenschappen n.e.g.

3143 Boswachters, bos- en natuurbeheerders

3110 (vangnet) Vakspecialisten natuur- en technische wetenschappen

3000 (vangnet) Vakspecialisten

3117 Technici delfstofwinning en metallurgie

3142 Vakspecialisten landbouw

3100 (vangnet) Vakspecialisten natuur- en technische wetenschappen

3116 Procestechnici (petro)chemische industrie

3140 (vangnet) Vakspecialisten levenswetenschappen, landbouw en natuurbeheer

0722-Productieleiders industrie en bouw

3122 Toezichthoudend personeel in de industrie

3123 Toezichthoudend personeel in de bouwnijverheid

3121 Toezichthoudend personeel in de mijnbouw

3120 (vangnet) Toezichthoudend personeel in de mijnbouw, de industrie en de bouwnijverheid

0723-Procesoperators

3133 Procesoperators chemische installaties

3139 Procesoperators n.e.g.

3130 (vangnet) Procesoperators

3134 Procesoperators aardolie- en aardgasraffinaderijen

3132 Procesoperators verbrandingsovens en waterzuiveringsinstallaties

3135 Procesoperators hoogovens

3131 Procesoperators elektriciteitscentrales

073-Bouwarbeiders

0731-Bouwarbeiders ruwbouw

7112 Stratenmakers, metselaars

7119 Steigerbouwers, bouwarbeiders ruwbouw n.e.g.

7111 Allround bouwvakkers, kleine bouwaannemers

7114 Betonwerkers, betonafwerkers

7113 Steenhouwers, -bewerkers en -snijders

7100 (vangnet) Bouwarbeiders, m.u.v. elektriciens

7110 (vangnet) Bouwarbeiders ruwbouw

0732-Timmerlieden

7115 Timmerlieden

0733-Bouwarbeiders afbouw

7122 Vloerleggers en tegelzetters

7123 Stukadoors

7127 Installateurs luchtbehandeling en koeltechniek

7121 Dakdekkers

7125 Glaszetters

7124 Isoleerders

7120 (vangnet) Bouwarbeiders afbouw

0734-Loodgieters en pijpfitters

7126 Loodgieters en pijpfitters

0735-Schilders en metaalspuiters

7131 Schilders en behangers

7132 Verf- en lakspuiters

7133 Schoorsteenvegers en gevelreinigers

7130 (vangnet) Schilders, schoonmakers bouwwerken

\begin{tabular}{|c|c|}
\hline 5 & 5 \\
\hline 3 & 4 \\
\hline 2 & 2 \\
\hline 2 & 2 \\
\hline 1 & 1 \\
\hline 1 & 1 \\
\hline 1 & 1 \\
\hline 0 & 0 \\
\hline 0 & 0 \\
\hline 0 & 0 \\
\hline 57 & \\
\hline 32 & 55 \\
\hline 23 & 40 \\
\hline 2 & 4 \\
\hline 1 & 1 \\
\hline 30 & \\
\hline 11 & 37 \\
\hline 8 & 27 \\
\hline 5 & 18 \\
\hline 2 & 6 \\
\hline 1 & 5 \\
\hline 1 & 4 \\
\hline 1 & 3 \\
\hline 266 & \\
\hline 64 & \\
\hline 25 & 39 \\
\hline 18 & 29 \\
\hline 9 & 15 \\
\hline 7 & 11 \\
\hline 1 & 2 \\
\hline 1 & 2 \\
\hline 1 & 2 \\
\hline 84 & \\
\hline 84 & 100 \\
\hline 40 & \\
\hline 10 & 24 \\
\hline 9 & 22 \\
\hline 8 & 20 \\
\hline 7 & 18 \\
\hline 4 & 9 \\
\hline 2 & 5 \\
\hline 1 & 1 \\
\hline 37 & \\
\hline 37 & 100 \\
\hline 40 & \\
\hline 32 & 78 \\
\hline 6 & 16 \\
\hline 2 & 6 \\
\hline 0 & 0 \\
\hline 195 & \\
\hline 47 & \\
\hline 21 & 44 \\
\hline 17 & 36 \\
\hline 3 & 7 \\
\hline
\end{tabular}

074-Metaalarbeiders, machinemonteurs

0741-Metaalbewerkers en constructiewerkers

7223 Machinestellers en -bedieners metaalproduktvervaardiging

7214 Constructiewerkers

7220 (vangnet) Metaalbewerkers, gereedschapsmakers

4

1

9

5

1

6


7222 Gereedschapsmakers

7221 Smeden, voorslagers en smeedperswerkers

7224 Metaalpolijsters, -slijpers en gereedschapslijpers

7211 Metaalgieters en kernmakers

7210 (vangnet) Plaat- en constructiewerkers, metaalgieters en lassers

7215 Takelaars en kabelsplitsers

0742-Lassers en plaatwerkers

7212 Lassers en snijders

7213 Plaatwerkers

0743-Automonteurs

7231 Automonteurs

0744-Machinemonteurs

7233 Monteurs industriÙle en landbouwmachines

7234 Rijwielmonteurs

7232 Vliegtuigmonteurs

7200 (vangnet) Metaalarbeiders, machinemonteurs

7230 (vangnet) Machinemonteurs, montage en reparatie

075-Voedselverwerkende beroepen en overige ambachten

0751-Slagers

7511 Slagers, vishandelaren

0752-Bakkers

7512 Bakkers en banketbakkers

0753-Productcontroleurs

7543 Productcontroleurs non-food

7549 Ambachtslieden n.e.g.

7515 Productcontroleurs voedingsmiddelen en dranken

7513 Zuivelbereiders

7516 Tabaksbereiders en vervaardigers van tabaksproducten

7541 Duikers

7544 Ongedierte- en onkruidbestrijders

7514 Bereiders van groente- en fruitconserven

7510 (vangnet) Slagers, bakkers en overige voedselverwerkende beroepen

7540 (vangnet) Overige ambachtslieden

7542 Springmeesters

7500 (vangnet) Voedselverwerkende beroepen, houtwerkers, kleermakers en andere ambachtslieder

0754-Meubelmakers, kleermakers en stoffeerders

7522 Meubelmakers

7534 Stoffeerders

7531 Kleermakers, bontwerkers en hoedenmakers

7533 Naaisters, borduursters

7523 Machinestellers en bedieners van houtbewerkingsmachines

7536 Schoenmakers

7532 Patroonmakers en snijders voor kleding

7535 Pelsbereiders en leerlooiers

7530 (vangnet) Kleermakers, stoffeerders, schoenmakers

7521 Houtbehandelaars

7520 (vangnet) Houtbehandelaars, meubelmakers

0755-Medewerkers drukkerij en kunstnijverheid

7322 Drukkers

7311 Fijninstrumentmakers en -reparateurs

7321 Drukwerkvoorbereiders

7313 Juweliers en bewerkers van edele metalen

7323 Grafisch nabewerkers en boekbinders

7316 Letterschilders, decoratieschilders, graveurs en etsers

5

\section{6}

3

2

1

1

1

65

35

100

77

11

7

3

2

126

17

17

19

19

21

8

\section{4}

4

3

0

\section{0}

\section{0}

0

0

0

0

0
0

34

13

7

5

3

3

\section{3}


7312 Vervaardigers en stemmers van muziekinstrumenten

7315 Glasblazers, -snijders, -slijpers en -polijsters

7320 (vangnet) Drukkerijmedewerkers

7317 Ambachtslieden werkend met hout, vlechtwerk

7318 Ambachtslieden werkend met textiel, leder

7300 (vangnet) Medewerkers drukkerij en kunstnijverheid

7319 Ambachtslieden traditionele ambachten n.e.g.

7314 Pottenbakkers

7310 (vangnet) Medewerkers kunstnijverheid

076-Elektriciens en elektronicamonteurs

0761-Elektriciens en elektronicamonteurs

7412 Elektromonteurs voertuigen, machines, motoren

7411 Elektriciens gebouwaansluitingen

7422 Monteurs ICT en telecommunicatie

7413 Monteur elektriciteitsnetten

7421 Elektronicamonteurs

7410 (vangnet) Installateurs en reparateurs van elektrische apparatuur

7400 (vangnet) Elektriciens en elektronicamonteurs

7420 (vangnet) Installateurs en reparateurs van elektronische en telecommunicatieapparatuur

077-Productiemachinebedieners en assemblagemedewerkers

0771-Productiemachinebedieners

8160 Machinebedieners vervaardiging voedingsmiddelen

8131 Bedieners machines en installaties vervaardiging chemische producten

8157 Wasmachinebedieners

8142 Machinebedieners vervaardiging kunststofprodukten

8100 (vangnet) Bedieners vaste machines en installaties

8189 Bedieners stationaire machines en installaties n.e.g.

8183 Verpakkings-, bottel- en etiketteringsmachinebedieners

8143 Machinebedieners vervaardiging papierprodukten

8121 Bedieners installaties metaalbewerkings- en verwerking

8181 Bedieners installaties vervaardiging glas en aardewerk

8171 Machinebedieners vervaardiging papierpulp en papier

8114 Machinebedieners vervaardiging cement, stenen en andere minerale producten

8122 Machinebedieners oppervlaktebehandelingen van metalen

8141 Machinebedieners vervaardiging rubberprodukten

8132 Machinebedieners fotolaboratorium

8172 Bedieners installaties houtbewerking

8000 (vangnet) Bedieners machines en installaties, assemblagemedewerkers

8152 Weefgetouw- en breimachinebedieners

8151 Machinebedieners vervaardiging textiele garens

8154 Machinebedieners bleken, verven en reinigen van weefsels

8153 Naaimachinebedieners

8120 (vangnet) Machinebedieners metaalbewerking, -verwerking en -oppervlaktebehandeling

8159 Machinebedieners vervaardiging textiel-, bont- en leerproducten n.e.g.

8180 (vangnet) Bedieners overige vaste machines en installaties

8113 Boorwerkers en boormeesters

8155 Machinebedieners bont- en leerbereiding

8156 Machinebedieners vervaardigen van schoeisel

8140 (vangnet) Machinebedieners vervaardiging rubber-, kunststof- of papierproducten

8150 (vangnet) Machinebedieners vervaardiging textiel-, bont- en leerproducten

8112 Bedieners installaties verwerking mineralen en gesteente

8182 Stoommachine en -ketelbedieners

8110 (vangnet) Bedieners mijninstallaties en installaties voor de verwerking van mineralen

8111 Delfstoffenwinnaars

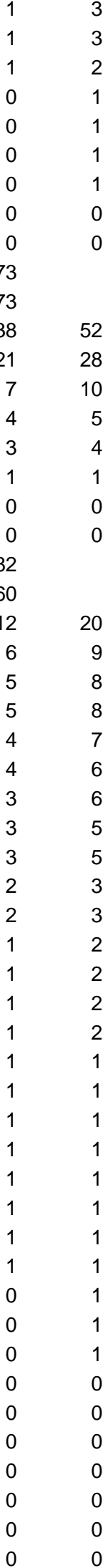


8170 (vangnet) Machinebedieners houtbewerking en papiervervaardiging

8130 (vangnet) Machinebedieners vervaardiging van chemische en fotografische producten

$\begin{array}{rr}0 & 0 \\ 0 & 0 \\ 22 & \\ 10 & 47 \\ 6 & 27 \\ 5 & 24 \\ 0 & 1 \\ 0 & 1 \\ 77 & \\ 77 & \\ 44 & 57 \\ 21 & 27 \\ 9 & 12 \\ 3 & 4 \\ 0 & 0 \\ 0 & 0 \\ 0 & 0 \\ 0 & 0 \\ 289 & \end{array}$

\section{8-ICT beroepen}

241

0811-Software- en applicatieontwikkelaars

2511 Systeemanalisten en ICT-adviseurs

178

2512 Softwareontwikkelaars

2514 Applicatieprogrammeurs

2513 Web- en multimediaontwikkelaars

2519 Software- en applicatieontwikkelaars en -analisten n.e.g.

2500 (vangnet) Specialisten informatie- en communicatietechnologie

2510 (vangnet) Software- en applicatieontwikkelaars en -analisten

0812-Databank- en netwerkspecialisten

2522 Systeembeheerders

2523 Netwerkspecialisten

2521 Ontwerpers en beheerders van databases

2529 Databank- en netwerkspecialisten n.e.g.

2520 (vangnet) Databank- en netwerkspecialisten

082-Vakspecialisten ICT

0821-Gebruikersondersteuning ICT

3512 Gebruikersondersteuners ICT en ICT-helpdeskmedewerkers

3514 Vakspecialisten website-ontwikkeling en -beheer

3513 Netwerk- en systeemtechnici

3500 (vangnet) Vakspecialisten informatie en communicatie

3511 Vakspecialisten informatie- en communicatietechnologie (hardware)

3510 (vangnet) Vakspecialisten informatie- en communicatietechnologie en gebruikersondersteuning

0822-Radio- en televisietechnici

3521 Beeld- en geluidstechnici radio en televisie

3522 Telecommunicatievakspecialisten

3520 (vangnet) Telecommunicatie-, radio- en televisietechnici

09-Agrarische beroepen

6111 Akkerbouwers en groentetelers volle grond $\quad 12$

6112 Telers van fruit en andere boom- en struikvruchten

6130 AgrariÙrs gemengd bedrijf

6100 (vangnet) Tuinders, akkerbouwers en veetelers

6000 (vangnet) Landbouwers, bosbouwers en vissers 


Beroepsklasse, -segment, -groep en ISCO2008

6110 (vangnet) Tuinders en akkerbouwers

\section{Bosbouwers}

6114 Telers van diverse gewassen

6200 (vangnet) Bosbouwers, vissers en jagers

0912-Hoveniers, tuinders en kwekers

6113 Hoveniers, tuinders en kwekers

0913-Veetelers

6121 Veehouders m.u.v. pluimvee

6122 Pluimveehouders

6224 Jagers en vallenzetters

6222 Vissers in binnen- en kustwateren

6221 Viskwekers en kwekers van schaaldieren

6129 Pelsdierenfokkers en veetelers n.e.g.

6120 (vangnet) Veetelers

6223 Vissers, op volle zee

6220 (vangnet) Vissers en jagers

6123 Bijenhouders en telers van andere insecten en wormen

092-Hulpkrachten landbouw

0921-Hulpkrachten landbouw

9214 Hulparbeiders tuinbouw

9211 Hulparbeiders akkerbouw

9216 Hulparbeiders visserij en visteelt

9212 Hulparbeiders veeteelt

9213 Hulparbeiders op gemengde bedrijven

9210 (vangnet) Hulparbeiders in de land- en bosbouw en de visserij

9215 Hulparbeiders bosbouw

9200 (vangnet) Hulparbeiders land- en bosbouw, visserij

10-Zorg en welzijn beroepen

101-Artsen, therapeuten en gespecialiseerd verpleegkundigen

1011-Artsen

2212 Medisch specialisten

2211 Huisartsen en basisartsen (niet in opleiding tot specialist)

2261 Tandartsen

2262 Apothekers

2250 Dierenartsen

2210 (vangnet) Artsen

1012-Gespecialiseerd verpleegkundigen

3

3

$0 \quad 1$

0

78

78

100

52

2221 Gespecialiseerd verpleegkundigen en verpleegkundig co $\div$ rdinatoren 2222 Verloskundigen

2220 (vangnet) Gespecialiseerd verpleegkundigen en verloskundigen

1013-Fysiotherapeuten

2264 Fysiotherapeuten

2269 Specialisten op het gebied van de gezondheidszorg n.e.g.

2266 Audiologen en logopedisten

2265 DiÙtisten en voedingsdeskundigen

2230 Alternatief genezers

2263 Specialisten op het gebied van de milieu- en arbeidshygiÙne

2267 Optometristen en orthoptisten

2240 Physician assistents

102-Specialisten op maatschappelijk gebied

1021-Maatschappelijk werkers

2635 Maatschappelijk werkers en specialistische sociale hulpverleners

2630 (vangnet) Sociaal wetenschappers, specialisten sociale hulpverlening 
1031-Laboranten

3212 Medisch en pathologisch laboranten

3211 Laboranten medische diagnostiek en therapie

3221 Verpleegkundigen (geen co $\div$ rdinerende of specialistische taken) 3222 Assistent-verloskundigen en kraamverpleegkundigen 3220 (vangnet) Verpleegkundigen en kraamverpleegkundigen

3412 Sociaal werkers, groeps- en woonbegeleiders

3411 Notarieel en juridisch assistenten en deurwaarders

3413 Pastoraal werkers

3410 (vangnet) Juridisch medewerkers, sociaal en pastoraal werkers

105-Verzorgenden

1051-Verzorgenden

5321 Verzorgenden intramuraal

5322 Verzorgenden thuiszorg

5320 (vangnet) Verzorgend personeel in de gezondheidszorg

5329 Assistenten gezondheidszorg n.e.g.

5300 (vangnet) Verzorgend personeel

11-Dienstverlenende beroepen

111-Medewerkers persoonlijke dienstverlening

1111-Reisbegeleiders

5111 Reisbegeleiders en stewards

5112 Conducteurs

5113 Reisleiders en gidsen

5110 (vangnet) Reisbegeleiders, conducteurs, reisleiders en gidsen

$1112-$ Koks

5120 Koks

3434 Chef-koks

97

3

0

68

27

5

54

19

8

7

15

13

7

3

3

.

5

6


1113-Kelners en barpersoneel

5131 Medewerkers bediening horeca

1114-Kappers en schoonheidsspecialisten

5141 Kappers

5142 Schoonheidsspecialisten

5140 (vangnet) Kappers, schoonheidsspecialisten

5-Conciërges en teamleiders schoonmaak

5153 ConciÙrges

5151 Teamleiders huishoudelijke diensten en schoonmaak

5152 Butlers en pensionhouders

5150 (vangnet) Teamleiders huishoudelijke diensten, conci - rges

116 -Verleners van overige persoonlijke diensten

5164 Dierverzorgers

5165 Rij-instructeurs

5163 Uitvaartmedewerkers en balsemers

5161 Astrologen, waarzeggers

5100 (vangnet) Medewerkers persoonlijke dienstverlening

5160 (vangnet) Overige verleners van persoonlijke diensten

5162 Gezelschapspersonen, buddy's en persoonlijk assistenten

5169 Verleners van persoonlijke diensten n.e.g.

112-Schoonmakers en keukenhulpen

9112 Schoonmakers in hotels, kantoren

9111 Schoonmakers in huishoudens

9110 (vangnet) Schoonmakers in huishoudens, hotels en kantoren

9122 Autowassers

9129 Industrieel schoonmakers, stralers, rioolreinigers en schoonmakers n.e.g.

9123 Glazenwassers

9121 Personeel voor het wassen en strijken met de hand

9100 (vangnet) Huishoudelijke hulpen en schoonmakers

9120 (vangnet) Autowassers, glazenwassers en overige schoonmakers

1122-Keukenhulpen

9412 Keukenhulpen

9411 Fastfoodbereiders

9400 (vangnet) Keukenhulpen en fastfoodbereiders

9410 (vangnet) Keukenhulpen en fastfoodbereiders

39

4

0

44

33

17

13

12

$0 \quad 1$

$0 \quad 0$

3152 Dekofficieren en loodsen

3153 Piloten, vlieginstructeurs

3151 Scheepswerktuigkundigen

3154 Luchtverkeersleiders

3150 (vangnet) Bestuurders en vakspecialisten schepen en vliegtuigen

3155 Elektrotechnicus luchtvaartveiligheid

1212-Chauffeurs auto's, taxi's en bestelwagens

8322 Chauffeurs auto's, taxi's en bestelwagens

8321 Bestuurders motorrijwielen

8320 (vangnet) Auto-, bestelwagenchauffeurs en bestuurders van motorrijwielen

1213-Buschauffeurs en trambestuurders

8331 Buschauffeurs en trambestuurders 
8332 Vrachtwagenchauffeurs

8300 (vangnet) Bestuurders voertuigen en bedieners mobiele installaties

8330 (vangnet) Vrachtwagen- en buschauffeurs

18

1215-Bedieners mobiele machines

8344 Heftruckchauffeurs

63

8343 Kraandrijvers en bedieningspersoneel mobiele kranen

8342 Bedieners grondverzetmachines

8341 Bedieners mobiele land- en bosbouwmachines

8311 Treinmachinisten

8350 Dekpersoneel op schepen

8312 Remmers, sein en wisselwachters

8340 (vangnet) Bedieners mobiele installaties

8310 (vangnet) Treinmachinisten

122-Hulpkrachten transport en logistiek

1221-Laders, lossers en vakkenvullers

9334 Vakkenvullers

9333 Laders en lossers

9331 Fietskoeriers en fietstaxichauffeurs

9332 Koetsiers en palfreniers

9330 (vangnet) Laders en lossers, vakkenvullers, fietskoeriers en koetsiers

1222-Vuilnisophalers en dagbladenbezorgers

9621 Boden, kruiers en bestellers

9622 Losse arbeiders

9629 Elementaire beroepen n.e.g.

9611 Vuilnisophalers en ophalers van afval voor recycling

9612 Vuilnissorteerders

9613 Straatvegers

9623 Meteropnemers en geldophalers verkoopautomaten

9520 Straatverkopers (m.u.v. voedsel)

9610 (vangnet) Vuilnisophalers en -verwerkers

9510 Kranten-, flyeruitdelers en andere op straat uitgeoefende dienstverlenende beroepen

9620 (vangnet) Andere elementaire beroepen

9500 (vangnet) Straatverkopers en op straat uitgeoefende dienstverlenende beroepen

9600 (vangnet) Vuilnisophalers en overige elementaire beroepen

13-Overig

131-Overig

1311-Overig

7000 (vangnet) Ambachtslieden

9000 (vangnet) Elementaire beroepen

2200 (vangnet) Specialisten gezondheidszorg

3300 (vangnet) Vakspecialisten bedrijfsbeheer en administratie

5000 (vangnet) Dienstverlenend personeel en verkopers

3400 (vangnet) Vakspecialisten op juridisch, maatschappelijk en cultureel gebied

2400 (vangnet) Specialisten bedrijfsbeheer en administratie

2260 (vangnet) Overige specialisten in de gezondheidszorg

6330 Agrariërs gemengd bedrijf, voor zelfvoorziening

4300 (vangnet) Boekhoudkundig medewerkers en voorraadbeheerders

2600 (vangnet) Juristen, sociaal wetenschappers en kunstenaars

4200 (vangnet) Klantvoorlichters, kassiers, incassomedewerkers

6300 (vangnet) Landbouwers, veetelers, vissers, jagers en verzamelaars, voor zelfvoorziening

6310 Landbouwers, voor zelfvoorziening

$\begin{array}{crr}9999 & 126 & 84 \\ & 22 & 14 \\ & 1 & 1 \\ & 1 & 0 \\ & 0 & 0 \\ & 0 & 0 \\ & 0 & 0 \\ 9997 & 0 & 0 \\ 9998 & 0 & 0 \\ & 0 & 0 \\ & 0 & 0 \\ & 0 & 0 \\ & 0 & 0 \\ & 0 & 0 \\ & 0 & 0 \\ & 0 & 0 \\ & 0 & 0\end{array}$


$\times 1.000$

-

aantal

4414 Openbare schrijvers

1113 Traditionele dorpshoofden

6320 Veetelers, voor zelfvoorziening

6340 Vissers, jagers, vallenzetters en verzamelaars, voor zelfvoorziening

9624 Waterdragers en brandhoutverzamelaars

$\begin{array}{rr}0 & 0 \\ 0 & 0 \\ 0 & 0 \\ 0 & 0 \\ 0 & 0 \\ 8338 & \end{array}$

Eindtotaal 
Bijlage 3a

Belangrijkste BGR128 beroepsgroep (oude ROA classificatie) per BRC2014 beroepsgroep, 2010-2012*

* voor 2012 geldt dat kwartaal 4 niet meegenomen is ivm ontbreken van SBC'92 codering van beroepen

${ }^{* *}$ minimaal $10 \%$ om BRC2014 beroepsgroep te kunnen tonen

\section{BRC2014}

beroepsgroep Oude BGR128 beroepsgroep

$\%$ **

0111 Docenten hoger onderwijs en hoogleraren

Beroepen overig

Docenten sociale vakken (1e graads)

11

Andere bgr128 beroepen

0112 Docenten beroepsgerichte vakken secundair onderwijs

Onderwijskundigen en pedagogen $\quad 24$

Beroepen overig

24
15

Docenten economisch-administratieve vakken (2e graads) 10

Andere bgr128 beroepen

51

0113 Docenten algemene vakken secundair onderwijs

Docenten talen en expressie $\quad 36$

Docenten letteren (1e graads) 24

Docenten exacte, medische en verzorgende vakken (2e graads) 15

Docenten sociale vakken (2e graads) 13

Docenten exacte, medische en verzorgende vakken (1e graads) 10

Andere bgr128 beroepen

0114 Leerkrachten basisonderwijs

$\begin{array}{lr}\text { Leraar basisonderwijs } & 90\end{array}$

Andere bgr128 beroepen $\quad 10$

0115 Onderwijskundigen en overige docenten

Onderwijskundig medewerkers $\quad 38$

Docenten talen en expressie $\quad 30$

$\begin{array}{ll}\text { Onderwijskundigen en pedagogen } & 21\end{array}$

0121 Sportinstructeurs

$\begin{array}{ll}\text { Andere bgr128 beroepen } & 11\end{array}$

Sportinstructeurs $\quad 66$

Zweminstructeurs $\quad 24$

$\begin{array}{ll}\text { Andere bgr128 beroepen } & 10\end{array}$

0131 Leidsters kinderopvang en onderwijsassistenten
Verzorgend personeel

$\begin{array}{ll}\text { Hulpkrachten horeca en verzorging } & 21\end{array}$

$\begin{array}{ll}\text { Andere bgr128 beroepen } & 10\end{array}$

0211 Bibliothecarissen en conservatoren

$\begin{array}{lr}\text { Bibliothecarissen } & 67\end{array}$

$\begin{array}{ll}\text { Taalkundigen } & 22\end{array}$

Andere bgr128 beroepen $\quad 11$

0212 Auteurs en taalkundigen

$\begin{array}{ll}\text { Tolken, vertalers en schrijvers } & 45\end{array}$

Journalisten $\quad 24$

$\begin{array}{lr}\text { Taalkundigen } & 17\end{array}$

0213 Journalisten

$\begin{array}{lr}\text { Andere bgr128 beroepen } & 14\end{array}$

0214 Beeldend kunstenaars

$\begin{array}{lr}\text { Journalisten } & 90\end{array}$

$\begin{array}{lr}\text { Andere bgr128 beroepen } & 10\end{array}$

$\begin{array}{ll}\text { Kunstenaars } & 100\end{array}$

0215 Uitvoerend kunstenaars

$\begin{array}{ll}\text { Kunstenaars } & 84\end{array}$

$\begin{array}{ll}\text { Andere bgr128 beroepen } & 16\end{array}$

0221 Grafisch vormgevers en productontwerpers
Grafisch ontwerpers

$\begin{array}{ll}\text { Grafisch ontwerpers } & 47 \\ \text { Kunstenaars } & 46\end{array}$

$\begin{array}{ll}\text { Andere bgr128 beroepen } & 7\end{array}$

0222 Fotografen en interieurontwerpers

Grafische vakkrachten $\quad 55$ 
BRC2014

beroepsgroep Oude BGR128 beroepsgroep $\%^{\text {** }}$

Architecten en bouwkundig projectleiders

$\begin{array}{ll}\text { Andere bgr128 beroepen } & 23\end{array}$

0311 Adviseurs marketing, public relations en sales
Commercieel medewerkers

$\begin{array}{ll}\text { Commercieel employés } & 71 \\ \text { Commers } & 14\end{array}$

Economen 13

Andere bgr128 beroepen 2

0321 Vertegenwoordigers en inkopers

Commercieel employés $\quad 80$

$\begin{array}{lr}\text { Commercieel medewerkers } & 17\end{array}$

Andere bgr128 beroepen 3

0331 Winkeliers en teamleiders detailhandel

Winkeliers

Andere bgr128 beroepen 18

0332 Verkoopmedewerkers detailhandel

Verkopers $\quad 85$

Commercieel employés 13

Andere bgr128 beroepen 2

0333 Kassamedewerkers

Verkopers $\quad 96$

Andere bgr128 beroepen 4

0334 Callcentermedewerkers outbound en overige verkopers
Commercieel employés

Ondersteunende administratieve hulpkrachten $\quad 17$

Winkeliers 13

Interieurverzorgers 13

$\begin{array}{ll}\text { Andere bgr128 beroepen } & 18\end{array}$

0411 Accountants

$\begin{array}{ll}\text { Accountants } & 93\end{array}$

$\begin{array}{lr}\text { Andere bgr128 beroepen } & 7\end{array}$

0412 Financieel specialisten en economen
Commercieel medewerkers

Economen 32

Andere bgr128 beroepen $\quad 1$

0413 Bedrijfskundigen en organisatieadviseurs
Organisatie-adviseurs

$\begin{array}{lr}\text { Organisatie-adviseurs } & 46 \\ \text { Organisatiedeskundigen } & 42\end{array}$

$\begin{array}{lr}\text { Technisch-bedrijfskundig medewerkers } & 11\end{array}$

0414 Beleidsadviseurs

Andere bgr128 beroepen

Sociaal-wetenschappelijk medewerkers $\quad 35$

Sociaal-wetenschappelijk onderzoekers 34

Andere bgr128 beroepen 31

0415 Specialisten personeels- en loopbaanontwikkeling

Medewerkers sociaal-cultureel werk en personeel en arbeid $\quad 75$

Activiteitenbegeleiders en medewerkers arbeidsbemiddeling 12

$\begin{array}{lr}\text { Andere bgr128 beroepen } & 13\end{array}$

0421 Boekhouders

Boekhouders en secretaresses $\quad 46$

Assistent accountants $\quad 31$

Commercieel medewerkers $\quad 11$

Andere bgr128 beroepen $\quad 12$

0422 Zakelijke dienstverleners

Commercieel employés $\quad 81$

$\begin{array}{lr}\text { Commercieel medewerkers } & 10 \\ \text { Andere bgr128 beroepen } & 9\end{array}$

0423 Directiesecretaresses

Boekhouders en secretaresses $\quad 51$

Assistent accountants $\quad 28$ 
BRC2014

$\begin{array}{ll}\text { Medisch secretaresses } & 17\end{array}$

Andere bgr128 beroepen $\quad 4$

0431 Administratief medewerkers

Boekhouders en secretaresses $\quad 59$

Receptionisten en administratieve employés $\quad 26$

0432 Secretaresses

Andere bgr128 beroepen $\quad 15$

Boekhouders en secretaresses $\quad 77$

0433 Receptionisten en telefonisten

Receptionisten en administratieve employés $\quad 23$

Receptionisten en administratieve employés $\quad 87$

$\begin{array}{ll}\text { Andere bgr128 beroepen } & 13\end{array}$

0434 Boekhoudkundig medewerkers

Boekhouders en secretaresses $\quad 35$

Commercieel employés 33

Receptionisten en administratieve employés $\quad 25$

Andere bgr128 beroepen $\quad 7$

0435 Transportplanners en logistiek medewerkers

$\begin{array}{ll}\text { Productieplanners } & 54\end{array}$

$\begin{array}{ll}\text { Organisatie-adviseurs } & 17\end{array}$

Administratieve transportemployés $\quad 10$

0511 Algemeen directeuren

$\begin{array}{lr}\text { Andere bgr128 beroepen } & 19\end{array}$

Managers 34

Commercieel medewerkers $\quad 29$

$\begin{array}{ll}\text { Leidinggevenden } & 20\end{array}$

Bedrijfshoofden $\quad 10$

$\begin{array}{ll}\text { Andere bgr128 beroepen } & 7\end{array}$

0521 Managers zakelijke en administratieve dienstverlening

$\begin{array}{ll}\text { Bedrijfshoofden } & 55 \\ \text { Managers } & 11\end{array}$

Assistent accountants $\quad 11$

Andere bgr128 beroepen 23

0522 Managers verkoop en marketing

$\begin{array}{ll}\text { Commercieel medewerkers } & 67\end{array}$

Andere bgr128 beroepen 33

0531 Managers productie

$\begin{array}{ll}\text { Aannemers en installateurs } & 21\end{array}$

$\begin{array}{ll}\text { Monteurs } & 11\end{array}$

0532 Managers logistiek

Andere bgr128 beroepen $\quad 68$

Vliegers, scheepskapiteins en leidinggevenden transport 29

Administratieve transportemployés $\quad 29$

\begin{tabular}{lr} 
Managers & 22 \\
\hline
\end{tabular}

0533 Managers ICT

Andere bgr128 beroepen $\quad 20$

Systeemanalisten $\quad 58$

Informatici 22

Andere bgr128 beroepen $\quad 20$

0534 Managers zorginstellingen

Afdelingshoofden zorginstelling $\quad 31$

Verzorgend personeel $\quad 24$

Managers 23

Andere bgr128 beroepen $\quad 22$

0535 Managers onderwijs

Managers $\quad 45$

Leraar basisonderwijs $\quad 34$

Leidinggevenden $\quad 12$

Andere bgr128 beroepen 9 
BRC2014

0536 Managers gespecialiseerde dienstverlening

Commercieel employés $\quad 20$

$\begin{array}{lr}\text { Commercieel medewerkers } & 18\end{array}$

Managers 17

Kunstenaars $\quad 15$

0541 Managers horeca

Andere bgr128 beroepen $\quad 30$

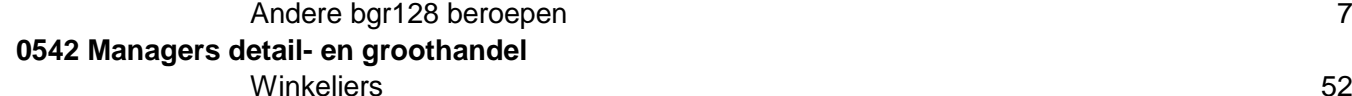

Bedrijfshoofden horeca $\quad 78$

Café- en snackbarhouders $\quad 15$

$\begin{array}{ll}\text { Winkeliers } & 52 \\ \text { Commercieel medewerkers } & 37\end{array}$

Andere bgr128 beroepen $\quad 11$

0543 Managers commerciële en persoonlijke dienstverlening
Bedrijfshoofden horeca

Commercieel medewerkers

Bedrijfshoofden 13

0611 Overheidsbestuurders

Andere bgr128 beroepen 3

Leidinggevenden $\quad 34$

Beroepen overig $\quad 25$

$\begin{array}{ll}\text { Managers } & 20\end{array}$

$\begin{array}{ll}\text { Andere bgr128 beroepen } & 21\end{array}$

0612 Overheidsambtenaren

$\begin{array}{ll}\text { Juridisch en fiscaal medewerkers } & 40\end{array}$

Assistent accountants 16

$\begin{array}{ll}\text { Boekhouders en secretaresses } & 15\end{array}$

$\begin{array}{ll}\text { Juristen } & 10\end{array}$

$\begin{array}{lr}\text { Andere bgr128 beroepen } & 19\end{array}$

0621 Juristen

$\begin{array}{ll}\text { Juristen } & 99\end{array}$

Andere bgr128 beroepen $\quad 1$

0631 Politie-inspecteurs

Politieagenten, onderofficieren en beveiligingsemployés 62

Politie-inspecteurs en officieren 36

Andere bgr128 beroepen 2

0632 Politie en brandweer

Politieagenten, onderofficieren en beveiligingsemployés 77

Brandweerlieden $\quad 16$

Andere bgr128 beroepen $\quad 7$

0633 Beveiligingspersoneel

$\begin{array}{ll}\text { Aspirant politieagenten, soldaten en beveiligingshulpkrachten } & 69\end{array}$

Activiteitenbegeleiders en medewerkers arbeidsbemiddeling 13

$\begin{array}{ll}\text { Kantoorhulpen, inpakkers en colporteurs } & 11\end{array}$

$\begin{array}{ll}\text { Andere bgr128 beroepen } & 7\end{array}$

0634 Militaire beroepen

Aspirant politieagenten, soldaten en beveiligingshulpkrachten $\quad 48$

Politieagenten, onderofficieren en beveiligingsemployés 35

Politie-inspecteurs en officieren $\quad 12$

Andere bgr128 beroepen $\quad 5$

0711 Biologen en natuurwetenschappers

Natuurwetenschappers $\quad 31$

Milieuhygiënisten en agrarisch vertegenwoordigers $\quad 26$

Beroepen overig $\quad 23$

Andere bgr128 beroepen $\quad 20$

0712 Ingenieurs (geen elektrotechniek)

Architecten en bouwkundig projectleiders $\quad 25$

Beroepen overig 23 
BRC2014

Werktuigbouwkundig ontwerpers en hoofden technische dienst 18

Weg- en waterbouwkundigen $\quad 12$

0713 Elektrotechnisch ingenieurs

Andere bgr128 beroepen $\quad 22$

Elektrotechnisch ontwerpers en bedrijfshoofden $\quad 47$

Elektrotechnici 29

Technisch systeemanalisten $\quad 12$

0714 Architecten

Andere bgr128 beroepen 12

Weg- en waterbouwkundigen $\quad 58$

Architecten en bouwkundig projectleiders $\quad 27$

Andere bgr128 beroepen $\quad 15$

0721 Technici bouwkunde en natuur

Aannemers en installateurs $\quad 20$

Beroepen overig $\quad 14$

$\begin{array}{ll}\text { Monteurs } & 10\end{array}$

Andere bgr128 beroepen 56

0722 Productieleiders industrie en bouw

Aannemers en installateurs $\quad 21$

Beroepen overig 20

Monteurs $\quad 14$

Procesoperators $\quad 13$

Andere bgr128 beroepen 32

0723 Procesoperators

$\begin{array}{ll}\text { Procesoperators } & 60\end{array}$

Mechanisch operators 31

0731 Bouwarbeiders ruwbouw

Bouwvakkers $\quad 45$

Productiemedewerkers $\quad 24$

$\begin{array}{ll}\text { Aannemers en installateurs } & 17\end{array}$

0732 Timmerlieden

$\begin{array}{lr}\text { Weg- en waterbouwkundige arbeiders } & 14\end{array}$

$\begin{array}{lr}\text { Bouwvakkers } & 49\end{array}$

Aannemers en installateurs $\quad 49$

Andere bgr128 beroepen $\quad 2$

Bouwvakkers $\quad 55$

Aannemers en installateurs $\quad 34$

$\begin{array}{ll}\text { Monteurs } & 11\end{array}$

0734 Loodgieters en pijpfitters

Andere bgr128 beroepen $\quad 0$

Aannemers en installateurs $\quad 73$

$\begin{array}{ll}\text { Productiemedewerkers } & 16\end{array}$

$\begin{array}{lr}\text { Weg- en waterbouwkundige arbeiders } & 10\end{array}$

Andere bgr128 beroepen $\quad 1$

0735 Schilders en metaalspuiters

Bouwvakkers $\quad 85$

$\begin{array}{lr}\text { Andere bgr128 beroepen } & 15\end{array}$

0741 Metaalbewerkers en constructiewerkers
Metaalarbeiders

Bankwerkers en lassers $\quad 32$

0742 Lassers en plaatwerkers

Metaalarbeiders $\quad 65$

Bankwerkers en lassers $\quad 29$

0743 Automonteurs

Andere bgr128 beroepen $\quad 6$

$\begin{array}{ll}\text { Monteurs } & 95\end{array}$ 
BRC2014

0744 Machinemonteurs

$\begin{array}{ll}\text { Monteurs } & 70\end{array}$

Beroepen overig $\quad 24$

Andere bgr128 beroepen $\quad 6$

0751 Slagers

$\begin{array}{lr}\text { Mechanisch operators } & 97\end{array}$

Andere bgr128 beroepen 3

0752 Bakkers

Bakkers en slagers $\quad 62$

Mechanisch operators 38

0753 Productcontroleurs

Andere bgr128 beroepen $\quad 0$

$\begin{array}{ll}\text { Productiemedewerkers } & 57\end{array}$

$\begin{array}{ll}\text { Agrarische vakkrachten } & 14\end{array}$

$\begin{array}{ll}\text { Agrarische arbeiders } & 11\end{array}$

Metaalarbeiders $\quad 10$

Andere bgr128 beroepen $\quad 8$

0754 Meubelmakers, kleermakers en stoffeerders

$\begin{array}{ll}\text { Aannemers en installateurs } & 34 \\ \text { Confectie-arbeiders } & 30\end{array}$

$\begin{array}{ll}\text { Bouwvakkers } & 26\end{array}$

Andere bgr128 beroepen $\quad 10$

0755 Medewerkers drukkerij en kunstnijverheid
Grafisch productiepersoneel

Grafische vakkrachten $\quad 24$

Productiemedewerkers $\quad 17$

$\begin{array}{ll}\text { Bankwerkers en lassers } & 14\end{array}$

Andere bgr128 beroepen $\quad 11$

0761 Elektriciens en elektronicamonteurs
Elektromonteurs

Monteurs en controleurs elektrotechnische producten $\quad 12$

$\begin{array}{ll}\text { Andere bgr128 beroepen } & 12\end{array}$

0771 Productiemachinebedieners

Mechanisch operators $\quad 33$

$\begin{array}{ll}\text { Productiemedewerkers } & 21\end{array}$

Procesoperators 14

Andere bgr128 beroepen $\quad 32$

0772 Assemblagemedewerkers

Productiemedewerkers $\quad 45$

$\begin{array}{ll}\text { Assembleurs } & 31\end{array}$

$\begin{array}{lr}\text { Metaalarbeiders } & 18\end{array}$

$\begin{array}{ll}\text { Andere bgr128 beroepen } & 6\end{array}$

0781 Hulpkrachten bouw en industrie

Kantoorhulpen, inpakkers en colporteurs $\quad 76$

Weg- en waterbouwkundige arbeiders $\quad 11$

$\begin{array}{ll}\text { Andere bgr128 beroepen } & 13\end{array}$

0811 Software- en applicatieontwikkelaars

Systeemanalisten $\quad 68$

Informatici 23

Andere bgr128 beroepen $\quad 9$

0812 Databank- en netwerkspecialisten

Programmeurs 65

$\begin{array}{lr}\text { Systeemanalisten } & 35\end{array}$

Andere bgr128 beroepen $\quad 0$

0821 Gebruikersondersteuning ICT

Programmeurs

0822 Radio- en televisietechnici

Andere bgr128 beroepen $\quad 1$ 
BRC2014

beroepsgroep Oude BGR128 beroepsgroep

0911 Land- en bosbouwers

Elektromonteurs $\quad 57$

$\begin{array}{ll}\text { Grafische vakkrachten } & 27\end{array}$

$\begin{array}{ll}\text { Andere bgr128 beroepen } & 16\end{array}$

Agrarische bedrijfshoofden $\quad 66$

Agrarische arbeiders $\quad 32$

Andere bgr128 beroepen 2

0912 Hoveniers, tuinders en kwekers

$\begin{array}{ll}\text { Agrarische arbeiders } & 69\end{array}$

Agrarische bedrijfshoofden $\quad 30$

0913 Veetelers

Andere bgr128 beroepen 1

Agrarische bedrijfshoofden $\quad 75$

$\begin{array}{ll}\text { Agrarische arbeiders } & 21\end{array}$

Andere bgr128 beroepen $\quad 4$

0921 Hulpkrachten landbouw

Agrarische hulparbeiders $\quad 76$

Agrarische arbeiders $\quad 19$

Andere bgr128 beroepen $\quad 5$

1011 Artsen

$\begin{array}{lr}\text { Artsen } & 89\end{array}$

$\begin{array}{ll}\text { Andere bgr128 beroepen } & 11\end{array}$

1012 Gespecialiseerd verpleegkundigen

Therapeuten en verpleegkundigen $\quad 80$

1013 Fysiotherapeuten

$\begin{array}{ll}\text { Andere bgr128 beroepen } & 20\end{array}$

Therapeuten en verpleegkundigen $\quad 80$

$\begin{array}{ll}\text { Andere bgr128 beroepen } & 20\end{array}$

1021 Maatschappelijk werkers

Medewerkers sociaal-cultureel werk en personeel en arbeid 51

Hoofden sociaal-cultureel werk en personeel en arbeid 17

Activiteitenbegeleiders en medewerkers arbeidsbemiddeling $\quad 15$

Beroepen overig

Andere bgr128 beroepen $\quad 5$

1022 Psychologen en sociologen

Sociaal-wetenschappelijk onderzoekers $\quad 43$

Onderwijskundigen en pedagogen 32

Andere bgr128 beroepen $\quad 25$

1031 Laboranten

Medisch analisten $\quad 69$

Apothekersassistenten en medisch laboranten $\quad 28$

Andere bgr128 beroepen 3

1032 Apothekersassistenten

$\begin{array}{ll}\text { Apothekersassistenten en medisch laboranten } & 100\end{array}$

1033 Verpleegkundigen (mbo)

Verplegenden en doktersassistenten 65

Verzorgend personeel 22

Verpleeghulpen en leerling-verpleegkundigen $\quad 12$

Andere bgr128 beroepen 1

1034 Medisch praktijkassistenten

Verplegenden en doktersassistenten $\quad 85$

$\begin{array}{lr}\text { Therapeuten en verpleegkundigen } & 11 \\ \text { Andere bgr128 beroepen } & 4\end{array}$

1035 Medisch vakspecialisten

Apothekersassistenten en medisch laboranten $\quad 43$

Verplegenden en doktersassistenten $\quad 15$

Therapeuten en verpleegkundigen 12

Andere bgr128 beroepen $\quad 30$

1041 Sociaal werkers, groeps- en woonbegeleiders 
BRC2014

1051 Verzorgenden

Activiteitenbegeleiders en medewerkers arbeidsbemiddeling 58

Medewerkers sociaal-cultureel werk en personeel en arbeid 22

Therapeuten en verpleegkundigen

Andere bgr128 beroepen

Ziekenverzorgenden

Hulpkrachten horeca en verzorging

Verzorgend personeel

Verpleeghulpen en leerling-verpleegkundigen

Andere bgr128 beroepen

1111 Reisbegeleiders

$\begin{array}{ll}\text { Stewards } & 64\end{array}$

Schippers en conducteurs $\quad 24$

1112 Koks

Andere bgr128 beroepen $\quad 12$

Verzorgend personeel $\quad 58$

Hulpkrachten horeca en verzorging 31

1113 Kelners en barpersoneel

Andere bgr128 beroepen $\quad 11$

$\begin{array}{ll}\text { Hulpkrachten horeca en verzorging } & 64\end{array}$

Interieurverzorgers $\quad 33$

Andere bgr128 beroepen 3

1114 Kappers en schoonheidsspecialisten
Verzorgend personeel

$\begin{array}{ll}\text { Hulpkrachten horeca en verzorging } & 14\end{array}$

1115 Conciërges en teamleiders schoonmaak

$\begin{array}{ll}\text { Conciërges } & 86\end{array}$

$\begin{array}{ll}\text { Andere bgr128 beroepen } & 14\end{array}$

1116 Verleners van overige persoonlijke diensten
Rij-instructeurs

Verplegenden en doktersassistenten $\quad 18$

$\begin{array}{lr}\text { Café- en snackbarhouders } & 15\end{array}$

$\begin{array}{ll}\text { Agrarische arbeiders } & 12\end{array}$

1121 Schoonmakers

Andere bgr128 beroepen $\quad 19$

1122 Keukenhulpen

$\begin{array}{ll}\text { Interieurverzorgers } & 79\end{array}$

$\begin{array}{lr}\text { Hulpkrachten horeca en verzorging } & 18\end{array}$

Andere bgr128 beroepen 3

1211 Dekofficieren en piloten

$\begin{array}{ll}\text { Interieurverzorgers } & 70\end{array}$

$\begin{array}{ll}\text { Hulpkrachten horeca en verzorging } & 30\end{array}$

Vliegers, scheepskapiteins en leidinggevenden transport $\quad 49$

$\begin{array}{lr}\text { Schippers en conducteurs } & 41\end{array}$

$\begin{array}{lr}\text { Andere bgr128 beroepen } & 10\end{array}$

1212 Chauffeurs auto's, taxi's en bestelwagens
Chauffeurs

Andere bgr128 beroepen $\quad 1$

$\begin{array}{cr}1213 \text { Buschauffeurs en trambestuurders } & 100 \\ \text { Chauffeurs }\end{array}$

1214 Vrachtwagenchauffeurs
Chauffeurs

1215 Bedieners mobiele machines

Chauffeurs $\quad 42$

$\begin{array}{lr}\text { Monteurs } & 27\end{array}$

$\begin{array}{ll}\text { Weg- en waterbouwkundige vakkrachten } & 19\end{array}$

1221 Laders, lossers en vakkenvullers 
BRC2014

beroepsgroep Oude BGR128 beroepsgroep

$\%$ **

Laders en lossers

73

Vakkenvullers

25

Andere bgr128 beroepen

2

1222 Vuilnisophalers en dagbladenbezorgers

Laders en lossers

60

Productiemedewerkers

20

Kantoorhulpen, inpakkers en colporteurs

19

1311 Overig

Andere bgr128 beroepen

1

Beroepen overig

100 


\section{Bijlage 3b}

Belangrijkste BRC2014 beroepsgroep per BGR128 beroepsgroep (oude ROA classificatie), 2010-2012*

* voor 2012 geldt dat kwartaal 4 niet meegenomen is ivm ontbreken van SBC'92 codering van beroepen

** minimaal 10\% om BRC2014 beroepsgroep te kunnen tonen

Oude BGR128

beroepsgroep

Leraar basisonderwijs

0114 Leerkrachten basisonderwijs

Andere BRC2014 beroepsgroepen

Docenten exacte, medische en verzorgende vakken (2e graads)

0113 Docenten algemene vakken secundair onderwijs

0112 Docenten beroepsgerichte vakken secundair onderwijs

Andere BRC2014 beroepsgroepen

Docenten exacte, medische en verzorgende vakken (1e graads) 0113 Docenten algemene vakken secundair onderwijs 63

0111 Docenten hoger onderwijs en hoogleraren 24

0112 Docenten beroepsgerichte vakken secundair onderwijs $\quad 13$

Docenten landbouw en techniek (2e graads)

0114 Leerkrachten basisonderwijs

0112 Docenten beroepsgerichte vakken secundair onderwijs Andere BRC2014 beroepsgroepen

Docenten landbouw en techniek (1e graads)

0114 Leerkrachten basisonderwijs

0111 Docenten hoger onderwijs en hoogleraren

Docenten economisch-administratieve vakken (2e graads)

0112 Docenten beroepsgerichte vakken secundair onderwijs $\quad 91$

Andere BRC2014 beroepsgroepen

Docenten economisch-administratieve vakken (1e graads)

0112 Docenten beroepsgerichte vakken secundair onderwijs 63

Docenten talen en expressie

0111 Docenten hoger onderwijs en hoogleraren $\quad 37$

0113 Docenten algemene vakken secundair onderwijs

0115 Onderwijskundigen en overige docenten 23

0112 Docenten beroepsgerichte vakken secundair onderwijs $\quad 11$

Docenten letteren (1e graads)

Andere BRC2014 beroepsgroepen

0113 Docenten algemene vakken secundair onderwijs 72

0112 Docenten beroepsgerichte vakken secundair onderwijs 18

Andere BRC2014 beroepsgroepen $\quad 10$

Docenten sociale vakken (2e graads)

0113 Docenten algemene vakken secundair onderwijs 63

0112 Docenten beroepsgerichte vakken secundair onderwijs 30

Docenten sociale vakken (1e graads)

$\begin{array}{ll}\text { Andere BRC2014 beroepsgroepen } & 7\end{array}$

0111 Docenten hoger onderwijs en hoogleraren $\quad 47$

0112 Docenten beroepsgerichte vakken secundair onderwijs 34

0113 Docenten algemene vakken secundair onderwijs 18

Andere BRC2014 beroepsgroepen $\quad 1$

Docenten 2e graads zonder specialisatie

0114 Leerkrachten basisonderwijs 91

Andere BRC2014 beroepsgroepen 9

Docent 1e graads zonder specialisatie

0114 Leerkrachten basisonderwijs 95

Onderwijskundig medewerkers

Andere BRC2014 beroepsgroepen

0115 Onderwijskundigen en overige docenten 96

Andere BRC2014 beroepsgroepen

Onderwijskundigen en pedagogen

0112 Docenten beroepsgerichte vakken secundair onderwijs 43

1022 Psychologen en sociologen 


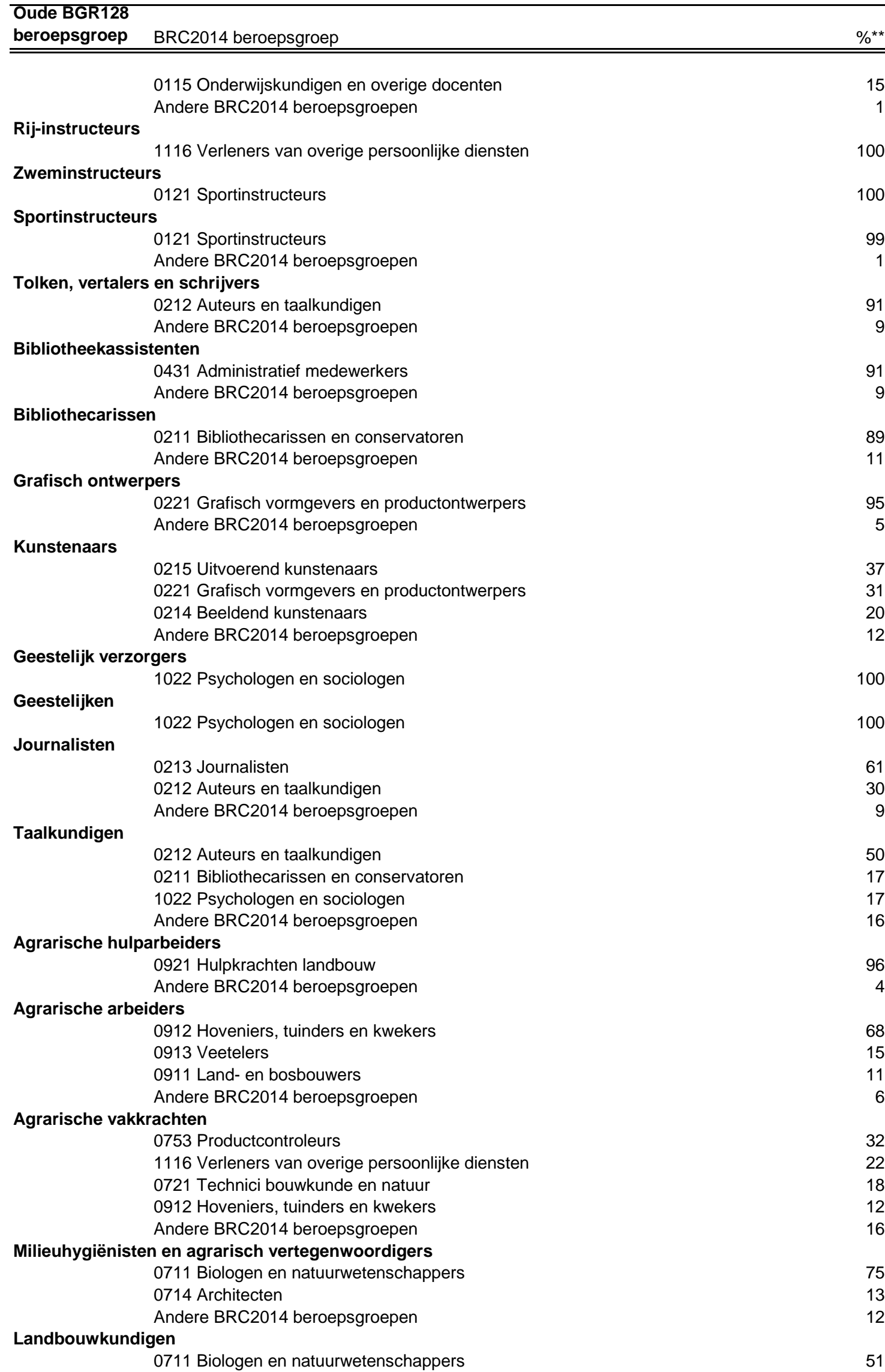


0714 Architecten

0522 Managers verkoop en marketing 16

Andere BRC2014 beroepsgroepen 14

Landbouwmachinebestuurders en vissers

1215 Bedieners mobiele machines $\quad 68$

0913 Veetelers

Andere BRC2014 beroepsgroepen

Agrarische bedrijfshoofden

0913 Veetelers $\quad 49$

0912 Hoveniers, tuinders en kwekers $\quad 28$

0911 Land- en bosbouwers $\quad 21$

Productiemedewerkers

Andere BRC2014 beroepsgroepen $\quad 2$

0731 Bouwarbeiders ruwbouw $\quad 21$

0771 Productiemachinebedieners 16

0753 Productcontroleurs $\quad 12$

Laboratorium-assistenten

Andere BRC2014 beroepsgroepen $\quad 51$

$\begin{array}{ll}1034 \text { Medisch praktijkassistenten } & 67\end{array}$

0721 Technici bouwkunde en natuur 33

Laboranten

0721 Technici bouwkunde en natuur $\quad 94$

Technisch analisten

Andere BRC2014 beroepsgroepen $\quad 6$

$\begin{array}{ll}0721 \text { Technici bouwkunde en natuur } & 77\end{array}$

0711 Biologen en natuurwetenschappers $\quad 11$

0414 Beleidsadviseurs $\quad 11$

Natuurwetenschappers

Andere BRC2014 beroepsgroepen $\quad 1$

Conciërges

0711 Biologen en natuurwetenschappers $\quad 84$

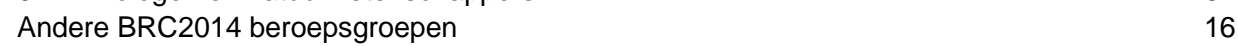

1115 Conciërges en teamleiders schoonmaak 99

Hoofden technische dienst

Andere BRC2014 beroepsgroepen 1

0722 Productieleiders industrie en bouw

0721 Technici bouwkunde en natuur $\quad 30$

0755 Medewerkers drukkerij en kunstnijverheid $\quad 15$

Werktuigbouwkundigen

Andere BRC2014 beroepsgroepen 2

0712 Ingenieurs (geen elektrotechniek) $\quad 49$

0522 Managers verkoop en marketing $\quad 40$

$\begin{array}{lr}0721 \text { Technici bouwkunde en natuur } & 10\end{array}$

Bouwvakkers

$\begin{array}{ll}\text { Andere BRC2014 beroepsgroepen } & 1\end{array}$

0732 Timmerlieden $\quad 27$

0735 Schilders en metaalspuiters $\quad 23$

$\begin{array}{ll}0731 \text { Bouwarbeiders ruwbouw } & 21\end{array}$

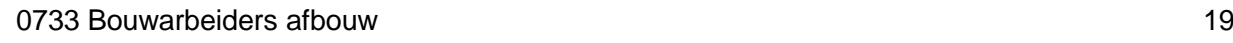

Aannemers en installateurs

Andere BRC2014 beroepsgroepen $\quad 10$

0732 Timmerlieden $\quad 26$

0721 Technici bouwkunde en natuur 16

0734 Loodgieters en pijpfitters $\quad 11$

0733 Bouwarbeiders afbouw 11

0722 Productieleiders industrie en bouw 10

Andere BRC2014 beroepsgroepen $\quad 26$

Architecten en bouwkundig projectleiders

0712 Ingenieurs (geen elektrotechniek) $\quad 41$ 
0721 Technici bouwkunde en natuur 18

0714 Architecten 10

0531 Managers productie $\quad 10$

Andere BRC2014 beroepsgroepen $\quad 21$

Weg- en waterbouwkundigen

0714 Architecten $\quad 47$

0712 Ingenieurs (geen elektrotechniek) 41

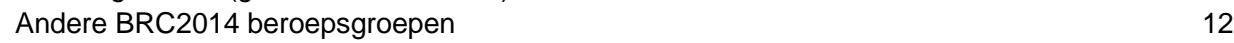

Weg- en waterbouwkundige arbeiders

0731 Bouwarbeiders ruwbouw 53

0781 Hulpkrachten bouw en industrie $\quad 31$

0734 Loodgieters en pijpfitters 12

Andere BRC2014 beroepsgroepen $\quad 4$

Weg- en waterbouwkundige vakkrachten

1215 Bedieners mobiele machines

0722 Productieleiders industrie en bouw $\quad 19$

0531 Managers productie 15

0721 Technici bouwkunde en natuur 13

Andere BRC2014 beroepsgroepen

Weg- en waterbouwkundig ontwerpers en projectleiders
0712 Ingenieurs (geen elektrotechniek)

0721 Technici bouwkunde en natuur 19

0714 Architecten 12

0722 Productieleiders industrie en bouw 11

Metaalarbeiders

Andere BRC2014 beroepsgroepen $\quad 6$

0741 Metaalbewerkers en constructiewerkers 52

0742 Lassers en plaatwerkers 36

Bankwerkers en lassers

Andere BRC2014 beroepsgroepen 12

0741 Metaalbewerkers en constructiewerkers 38

0742 Lassers en plaatwerkers $\quad 22$

Andere BRC2014 beroepsgroepen $\quad 40$

Bedrijfshoofden metaalbewerking

0131 Leidsters kinderopvang en onderwijsassistenten $\quad 44$

0531 Managers productie $\quad 40$

0721 Technici bouwkunde en natuur 12

Assembleurs

Andere BRC2014 beroepsgroepen $\quad 4$

0744 Machinemonteurs $\quad 39$

0772 Assemblagemedewerkers $\quad 30$

0743 Automonteurs $\quad 16$

Andere BRC2014 beroepsgroepen $\quad 15$

Monteurs

0744 Machinemonteurs $\quad 33$

0743 Automonteurs 26

1215 Bedieners mobiele machines

Andere BRC2014 beroepsgroepen $\quad 31$

Werktuigbouwkundig ontwerpers en hoofden technische dienst
0712 Ingenieurs (geen elektrotechniek)

$\begin{array}{ll}0721 \text { Technici bouwkunde en natuur } & 17\end{array}$

Andere BRC2014 beroepsgroepen $\quad 28$

Elektronicamonteurs

0761 Elektriciens en elektronicamonteurs $\quad 85$

0721 Technici bouwkunde en natuur $\quad 12$

Andere BRC2014 beroepsgroepen 3

Monteurs en controleurs elektrotechnische producten

0761 Elektriciens en elektronicamonteurs $\quad 88$

Andere BRC2014 beroepsgroepen 12 
Oude BGR128

beroepsgroep

BRC2014 beroepsgroep

Elektromonteurs

0761 Elektriciens en elektronicamonteurs

0721 Technici bouwkunde en natuur 10

Andere BRC2014 beroepsgroepen 14

Elektrotechnisch ontwerpers en bedrijfshoofden

0713 Elektrotechnisch ingenieurs 63

0531 Managers productie $\quad 17$

Andere BRC2014 beroepsgroepen 20

Elektrotechnici

0713 Elektrotechnisch ingenieurs 70

0811 Software- en applicatieontwikkelaars

Grafisch productiepersoneel

Andere BRC2014 beroepsgroepen $\quad 4$

0755 Medewerkers drukkerij en kunstnijverheid

0771 Productiemachinebedieners $\quad 21$

Grafische vakkrachten

0222 Fotografen en interieurontwerpers 44

0755 Medewerkers drukkerij en kunstnijverheid

0822 Radio- en televisietechnici 11

0531 Managers productie 10

Andere BRC2014 beroepsgroepen 10

Mechanisch operators

0771 Productiemachinebedieners 37

0723 Procesoperators 26

0751 Slagers $\quad 25$

Andere BRC2014 beroepsgroepen 12

Procesoperators

0723 Procesoperators 59

0722 Productieleiders industrie en bouw

0771 Productiemachinebedieners 19

Procestechnologen

Andere BRC2014 beroepsgroepen

0531 Managers productie 48

0712 Ingenieurs (geen elektrotechniek)

Andere BRC2014 beroepsgroepen 9

Materiaalkundigen

0221 Grafisch vormgevers en productontwerpers 33

0531 Managers productie 33

0712 Ingenieurs (geen elektrotechniek) 31

Confectie-arbeiders

Andere BRC2014 beroepsgroepen

0754 Meubelmakers, kleermakers en stoffeerders $\quad 77$

0771 Productiemachinebedieners 17

Andere BRC2014 beroepsgroepen 6

Schoen- en kleermakers

0754 Meubelmakers, kleermakers en stoffeerders 78

0531 Managers productie 13

Andere BRC2014 beroepsgroepen 9

Laders en lossers

1221 Laders, lossers en vakkenvullers

1222 Vuilnisophalers en dagbladenbezorgers $\quad 16$

Andere BRC2014 beroepsgroepen 1

Chauffeurs

1214 Vrachtwagenchauffeurs 50

1212 Chauffeurs auto's, taxi's en bestelwagens 16

1215 Bedieners mobiele machines

0431 Administratief medewerkers $\quad 11$

Schippers en conducteurs

Andere BRC2014 beroepsgroepen $\quad 10$ 


\begin{tabular}{|c|c|c|}
\hline $\begin{array}{l}\text { Oude BGR128 } \\
\text { beroepsgroep }\end{array}$ & BRC2014 beroepsgroep & $\%$ ** \\
\hline & 1211 Dekofficieren en piloten & \\
\hline & 1111 Reisbegeleiders & 2 \\
\hline & 0435 Transportplanners en logistiek medewerkers & 1 \\
\hline & Andere BRC2014 beroepsgroepen & 1 \\
\hline \multicolumn{3}{|c|}{ Vliegers, scheepskapiteins en leidinggevenden transport } \\
\hline & 1211 Dekofficieren en piloten & \\
\hline & 0532 Managers logistiek & 3 \\
\hline & Andere BRC2014 beroepsgroepen & \\
\hline \multicolumn{3}{|l|}{ Stewards } \\
\hline & 1111 Reisbegeleiders & 10 \\
\hline \multicolumn{3}{|c|}{ Verpleeghulpen en leerling-verpleegkundigen } \\
\hline & 1051 Verzorgenden & \\
\hline & 1033 Verpleegkundigen (mbo) & \\
\hline & Andere BRC2014 beroepsgroepen & \\
\hline \multicolumn{3}{|c|}{ Verplegenden en doktersassistenten } \\
\hline & 1033 Verpleegkundigen (mbo) & \\
\hline & 1034 Medisch praktijkassistenten & \\
\hline & Andere BRC2014 beroepsgroepen & \\
\hline \multicolumn{3}{|c|}{ Therapeuten en verpleegkundigen } \\
\hline & 1012 Gespecialiseerd verpleegkundigen & \\
\hline & 1013 Fysiotherapeuten & \\
\hline & 1041 Sociaal werkers, groeps- en woonbegeleiders & \\
\hline & Andere BRC2014 beroepsgroepen & \\
\hline \multicolumn{3}{|l|}{ Artsen } \\
\hline & 1011 Artsen & \\
\hline & Andere BRC2014 beroepsgroepen & \\
\hline \multicolumn{3}{|c|}{ Apothekersassistenten en medisch laboranten } \\
\hline & 1032 Apothekersassistenten & \\
\hline & 1035 Medisch vakspecialisten & \\
\hline & 1031 Laboranten & \\
\hline & Andere BRC2014 beroepsgroepen & \\
\hline \multicolumn{3}{|c|}{ Medisch analisten } \\
\hline & 1031 Laboranten & \\
\hline \multirow{2}{*}{\multicolumn{3}{|c|}{ 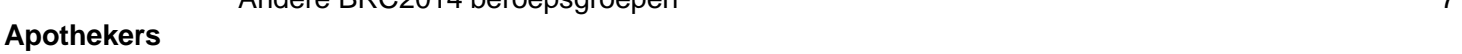 }} \\
\hline & & \\
\hline & 1011 Artsen & \\
\hline & 1031 Laboranten & \\
\hline & 0711 Biologen en natuurwetenschappers & \\
\hline & 0531 Managers productie & \\
\hline & Andere BRC2014 beroepsgroepen & \\
\hline \multicolumn{3}{|c|}{ Afdelingshoofden zorginstelling } \\
\hline & 0534 Managers zorginstellingen & \\
\hline & 1021 Maatschappelijk werkers & \\
\hline & Andere BRC2014 beroepsgroepen & \\
\hline \multicolumn{3}{|c|}{ Kantoorhulpen, inpakkers en colporteurs } \\
\hline & 0781 Hulpkrachten bouw en industrie & \\
\hline & 1222 Vuilnisophalers en dagbladenbezorgers & \\
\hline & Andere BRC2014 beroepsgroepen & \\
\hline \multicolumn{3}{|c|}{ Ondersteunende administratieve hulpkrachten } \\
\hline & 0334 Callcentermedewerkers outbound en overige verkopers & \\
\hline & 0433 Receptionisten en telefonisten & \\
\hline & 0431 Administratief medewerkers & \\
\hline & 0121 Sportinstructeurs & \\
\hline & Andere BRC2014 beroepsgroepen & \\
\hline \multicolumn{3}{|c|}{ Bedrijfshoofden } \\
\hline & 0521 Managers zakelijke en administratieve dienstverlening & \\
\hline & Andere BRC2014 beroepsgroepen & \\
\hline Economen & - & \\
\hline
\end{tabular}


Oude BGR128

beroepsgroep

BRC2014 beroepsgroep

$\%$ **

0311 Adviseurs marketing, public relations en sales

Andere BRC2014 beroepsgroepen

Productieplanners

0435 Transportplanners en logistiek medewerkers 100

Organisatie-adviseurs

0413 Bedrijfskundigen en organisatieadviseurs 58

0435 Transportplanners en logistiek medewerkers 37

Andere BRC2014 beroepsgroepen

Organisatiedeskundigen

0413 Bedrijfskundigen en organisatieadviseurs 89

Andere BRC2014 beroepsgroepen 11

Receptionisten en administratieve employés

0433 Receptionisten en telefonisten

0431 Administratief medewerkers 39

Andere BRC2014 beroepsgroepen $\quad 20$

Boekhouders en secretaresses

0431 Administratief medewerkers

0421 Boekhouders $\quad 17$

0432 Secretaresses $\quad 12$

0423 Directiesecretaresses 10

Andere BRC2014 beroepsgroepen 11

Assistent accountants

0421 Boekhouders $\quad 49$

0423 Directiesecretaresses 24

0612 Overheidsambtenaren $\quad 12$

Andere BRC2014 beroepsgroepen 15

Accountants

0411 Accountants 91

Andere BRC2014 beroepsgroepen 9

Verzekeringsagenten

0612 Overheidsambtenaren 59

0434 Boekhoudkundig medewerkers 23

0334 Callcentermedewerkers outbound en overige verkopers 12

Andere BRC2014 beroepsgroepen 6

Commercieel employés

0422 Zakelijke dienstverleners 36

0321 Vertegenwoordigers en inkopers $\quad 19$

0332 Verkoopmedewerkers detailhandel 14

Andere BRC2014 beroepsgroepen 31

Commercieel medewerkers

0311 Adviseurs marketing, public relations en sales 32

0412 Financieel specialisten en economen 14

0542 Managers detail- en groothandel 14

0522 Managers verkoop en marketing 13

Andere BRC2014 beroepsgroepen $\quad 27$

Technisch-commercieel employés

0721 Technici bouwkunde en natuur 60

0222 Fotografen en interieurontwerpers 12

0311 Adviseurs marketing, public relations en sales 12

Andere BRC2014 beroepsgroepen 16

Technisch-bedrijfskundig medewerkers

0413 Bedrijfskundigen en organisatieadviseurs

0721 Technici bouwkunde en natuur 17

0415 Specialisten personeels- en loopbaanontwikkeling 16

Juridisch en fiscaal medewerkers

Andere BRC2014 beroepsgroepen 13

0612 Overheidsambtenaren $\quad 85$

1041 Sociaal werkers, groeps- en woonbegeleiders 15

Andere BRC2014 beroepsgroepen 
Oude BGR128

beroepsgroep

Juridisch, bestuurlijk medewerkers

0414 Beleidsadviseurs

0612 Overheidsambtenaren

0611 Overheidsbestuurders

Juristen

Andere BRC2014 beroepsgroepen 3

0621 Juristen 79

Andere BRC2014 beroepsgroepen 21

Administratieve transportemployés

0435 Transportplanners en logistiek medewerkers 64

0532 Managers logistiek

Andere BRC2014 beroepsgroepen

Leidinggevenden

0611 Overheidsbestuurders 37

0511 Algemeen directeuren

0542 Managers detail- en groothandel 14

Andere BRC2014 beroepsgroepen

Managers

0511 Algemeen directeuren 20

0535 Managers onderwijs 14

0611 Overheidsbestuurders

0534 Managers zorginstellingen 11

Andere BRC2014 beroepsgroepen 43

Medisch secretaresses

0423 Directiesecretaresses 99

Andere BRC2014 beroepsgroepen

Programmeurs

0812 Databank- en netwerkspecialisten

0821 Gebruikersondersteuning ICT 19

Andere BRC2014 beroepsgroepen

Systeemanalisten

0811 Software- en applicatieontwikkelaars 69

0812 Databank- en netwerkspecialisten 23

Andere BRC2014 beroepsgroepen $\quad 8$

Informatici

0811 Software- en applicatieontwikkelaars 90

0533 Managers ICT 10

Technisch systeemanalisten

0811 Software- en applicatieontwikkelaars

0713 Elektrotechnisch ingenieurs 17

Andere BRC2014 beroepsgroepen

Activiteitenbegeleiders en medewerkers arbeidsbemiddeling

1041 Sociaal werkers, groeps- en woonbegeleiders

Andere BRC2014 beroepsgroepen $\quad 29$

Medewerkers sociaal-cultureel werk en personeel en arbeid

0415 Specialisten personeels- en loopbaanontwikkeling 44

1041 Sociaal werkers, groeps- en woonbegeleiders

1021 Maatschappelijk werkers

Andere BRC2014 beroepsgroepen 7

Hoofden sociaal-cultureel werk en personeel en arbeid
\[ 1021 \text { Maatschappelijk werkers } \]

0415 Specialisten personeels- en loopbaanontwikkeling 15

Andere BRC2014 beroepsgroepen

Sociaal-wetenschappelijk medewerkers

0414 Beleidsadviseurs

1022 Psychologen en sociologen 11

Sociaal-wetenschappelijk onderzoekers

1022 Psychologen en sociologen 55 


\begin{tabular}{|c|c|c|}
\hline $\begin{array}{l}\text { Oude BGR128 } \\
\text { beroepsgroep }\end{array}$ & BRC2014 beroepsgroep & $\%$ ** \\
\hline & 0414 Beleidsadviseurs & \\
\hline & Andere BRC2014 beroepsgroepen & 0 \\
\hline \multicolumn{3}{|l|}{ Vakkenvullers } \\
\hline & 1221 Laders, lossers en vakkenvullers & 91 \\
\hline & Andere BRC2014 beroepsgroepen & 9 \\
\hline \multicolumn{3}{|c|}{ Interieurverzorgers } \\
\hline & 1121 Schoonmakers & 65 \\
\hline & 1113 Kelners en barpersoneel & 23 \\
\hline & 1122 Keukenhulpen & 10 \\
\hline & Andere BRC2014 beroepsgroepen & 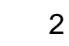 \\
\hline \multicolumn{3}{|l|}{ Verkopers } \\
\hline & 0332 Verkoopmedewerkers detailhandel & 81 \\
\hline & 0333 Kassamedewerkers & 16 \\
\hline & Andere BRC2014 beroepsgroepen & 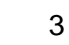 \\
\hline \multicolumn{3}{|l|}{ Winkeliers } \\
\hline & 0331 Winkeliers en teamleiders detailhandel & \\
\hline & 0542 Managers detail- en groothandel & 43 \\
\hline & Andere BRC2014 beroepsgroepen & 11 \\
\hline \multicolumn{3}{|c|}{ Hulpkrachten horeca en verzorging } \\
\hline & 1113 Kelners en barpersoneel & 37 \\
\hline & 1051 Verzorgenden & 24 \\
\hline & 1121 Schoonmakers & 12 \\
\hline & 0131 Leidsters kinderopvang en onderwijsassistenten & 11 \\
\hline & Andere BRC2014 beroepsgroepen & 1 \\
\hline \multicolumn{3}{|c|}{ Ziekenverzorgenden } \\
\hline & 1051 Verzorgenden & 96 \\
\hline & Andere BRC2014 beroepsgroepen & \\
\hline \multicolumn{3}{|c|}{ Verzorgend personeel } \\
\hline & 0131 Leidsters kinderopvang en onderwijsassistenten & 32 \\
\hline & 1114 Kappers en schoonheidsspecialisten & 22 \\
\hline & 1051 Verzorgenden & 17 \\
\hline & 1112 Koks & 13 \\
\hline & Andere BRC2014 beroepsgroepen & 16 \\
\hline \multicolumn{3}{|c|}{ Café- en snackbarhouders } \\
\hline & 0541 Managers horeca & 46 \\
\hline & 1116 Verleners van overige persoonlijke diensten & 30 \\
\hline & 1113 Kelners en barpersoneel & 18 \\
\hline & Andere BRC2014 beroepsgroepen & 6 \\
\hline \multicolumn{3}{|c|}{ Bedrijfshoofden horeca } \\
\hline & 0541 Managers horeca & 68 \\
\hline & 0543 Managers commerciële en persoonlijke dienstverlening & 1 \\
\hline & 1112 Koks & 10 \\
\hline & Andere BRC2014 beroepsgroepen & 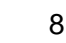 \\
\hline \multicolumn{3}{|c|}{ Bakkers en slagers } \\
\hline & 0752 Bakkers & $\varepsilon$ \\
\hline & 0331 Winkeliers en teamleiders detailhandel & 18 \\
\hline & Andere BRC2014 beroepsgroepen & 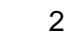 \\
\hline \multicolumn{3}{|c|}{ Aspirant politieagenten, soldaten en beveiligingshulpkrachten } \\
\hline & 0633 Beveiligingspersoneel & 6 \\
\hline & 0634 Militaire beroepen & 30 \\
\hline & Andere BRC2014 beroepsgroepen & 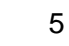 \\
\hline \multicolumn{3}{|c|}{ Politieagenten, onderofficieren en beveiligingsemployés } \\
\hline & 0632 Politie en brandweer & 5 \\
\hline & 0634 Militaire beroepen & 23 \\
\hline & 0631 Politie-inspecteurs & 16 \\
\hline & Andere BRC2014 beroepsgroepen & \\
\hline \multicolumn{3}{|c|}{ Politie-inspecteurs en officieren } \\
\hline & 0631 Politie-inspecteurs & 5 \\
\hline & 0634 Militaire beroepen & \\
\hline
\end{tabular}


Oude BGR128

beroepsgroep BRC2014 beroepsgroep

$\%$ **

Andere BRC2014 beroepsgroepen

1

Brandweerlieden

0632 Politie en brandweer

1013 Fysiotherapeuten

Beroepen overig

38

Andere BRC2014 beroepsgroepen 